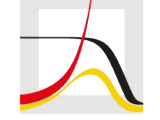

MAX PLANCK INSTITUTE

FOR DEMOGRAPHIC RESEARCH

Konrad-Zuse-Strasse 1 · D-18057 Rostock · Germany · Tel +49 (0) 3812081 - 0 · Fax +49 (0) 3812081 - 202 · www.demogr.mpg.de

MPIDR Working Paper WP 2022-003 I January 2022

https://doi.org/10.4054/MPIDR-WP-2022-003

\title{
Power relations and persistent low fertility among domestic workers in Brazil, Colombia, and Mexico
}

Andrés F. Castro Torres I castro@demogr.mpg.de Edith Yolanda Gutierrez Vazquez

Tereza Bernardes

This working paper has been approved for release by: Natalie Nitsche (nitsche@demogr.mpg.de),

Deputy Head of the Laboratory of Fertility and Well-Being.

(c) Copyright is held by the authors.

Working papers of the Max Planck Institute for Demographic Research receive only limited review. Views or opinions expressed in working papers are attributable to the authors and do not necessarily reflect those of the Institute. 


\title{
Power relations and persistent low fertility among domestic workers in Brazil, Colombia, and Mexico
}

\begin{abstract}
Our study offers a power-relations-based explanation for the "paradoxically" low and delayed fertility of live-in domestic workers, a social, ethnic, and economic minority, hitherto neglected in quantitative studies of fertility in Latin America and the Caribbean (LACar). This lack of attention relates to the limited scope of theories explaining fertility differentials and change. We challenge these paradigms by comparing the fertility patterns of two million domestic workers against those of women living in large cities, other urban areas, and rural areas using 12 census samples from Brazil, Colombia, and Mexico (1970-2010), the three largest countries in LACar. Comparing age-specific fertility measures across these groups and over time allows us to study reproduction differentials as embedded in power relations. Our results demonstrate that the very low and delayed fertility of live-in domestic workers emerges from the confluence of socioeconomic disadvantages throughout their life course. We also show that live-in domestic workers contributed to higher fertility among mistresses compared to women who did not employ live-in domestic workers. Together, these results underline the need to re-center research questions towards the social mechanisms, including power relations, underpinning unequal living conditions and their consequences for fertility and family patterns. The increasingly transnational nature of domestic work and the rising trends of socioeconomic inequalities worldwide renders the examination of minorities central for a deep understanding of family change beyond the LACar context.
\end{abstract}

\section{Introduction}

Spoiler alert! Alfonso Cuarón's 2018 film "Roma" portrays a typical middle-upper class Mexican family in 1970. The husband travels permanently due to his job, and his spouse stays at home taking care of their four children; they have a big house, two cars, and a dog. Two young indigenous women from a rural area co-reside with this family and take care of most household chores; both are low educated, and their families back home have minimal resources. Contrary to 
what the overarching evidence on the relationship between education, economic well-being, and fertility would predict, both had fewer children than the middle-upper class wife. Cleo, the youngest domestic worker, had only one pregnancy throughout the movie, ending as a miscarriage. Even though she could have more children afterward, it is doubtful she will reach a high parity. Characters like these are frequent in Latin American and the Caribbean (LACar) literature, films, and soap operas.

One should be cautious when analyzing literary and novelistic narratives and curious enough to examine family patterns among minority groups for at least two reasons. First, their contribution to productive and reproductive activities (directly and indirectly) is often hidden in official statistics and the public discourse. Despite long-dated claims for formal recognition and regulations to protect the rights of domestic workers, their working conditions are still far from optimal, and several still suffer from exploitation (Federici, 2000). According to the International Labor Organization, in 2010, 18 million women in LACar worked as domestic workers, representing slightly less than $20 \%$ of the female labor force (ILO, 2013). Second, their living conditions and life courses imply that overarching processes of societal transformation such as educational expansion and urbanization may have specific, potentially harmful, implications for them as new forms of exploitation emerge. The critical examination of family patterns among minority groups challenges mainstream explanations of demographic processes, frames demographic change within power relations, and opens the possibility for transformative family research.

Because low fertility and fertility decline associate with improvements in economic, social, and cultural capital, both at the individual (Castro Martin \& Juarez, 1995) and the population level (Shenk et al., 2013), the lower fertility among live-in domestic workers compared to high-class- 
urban women is a big puzzle for family sociologists. Some literature suggests that low fertility among lower-class women results from the diffusion of positive ideas about low fertility from high-class to low-class women (Quilodrán \& Juarez, 2009). Due to the lack of direct evidence to support claims about social learning of fertility ideals, studies often assume that co-residency implies the transmission of ideas; this diffusion becomes the cultural channel by which domestic workers "learn" and "enact" lower fertility.

This paper uses census data from Brazil, Colombia, and Mexico, to push forward an alternative narrative based on three arguments. First, we contend that objective living conditions (i.e., those that determine women's social class) are more significant for explaining the historically low fertility of domestic workers than the possible transmission of ideas from high- to low-class women. Second, we argue that the low fertility of domestic workers does not mean they carried a low reproductive burden. On the contrary, domestic workers contributed significantly to childrearing in high-class households while putting their family formation paths aside. Third, we use these two arguments to call attention to the necessity of understanding fertility change and differentials as processes embedded in power relations. The myths of modern subjectivity and modernity as the main drivers of demographic change have mistakenly relegated power imbalances as a factor in fertility variation. Our study demonstrates the importance of power differentials by comparing groups with fairly distinct social positions.

\section{Background}

Studies of racial, immigrant and sexual minorities have gained prominence in contemporary social science (Hill Collins \& Bilge, 2016). By departing from variable-based explanations and focusing on the structural factors underpinning differential demographic patterns among minority groups (e.g., racism instead of race, discrimination instead of sexual identity, social exclusion instead of 
migration status), this scholarship has provided new insights on the causes and the potential pathways to overcome inequality and social exclusion (Choo \& Ferree, 2010; Zuberi \& BonillaSilva, 2008). The methodological consequences of these lessons have started to reshape quantitative studies on the relationship between family and socioeconomic well-being (Williams \& Baker, 2021).

Less attention has been devoted to studying minorities whose vulnerable conditions are not attached to their immigrant, racial, and sexual background or identity, and whose contribution to overall demographic change is minor (e.g., ethnic and socioeconomic minorities outside of the U.S.). However, the relatively small representation of these groups in the population and their limited capacity for creating a political/social identity does not diminish their relevance for developing a deep understanding of family change and variation. On the contrary, the uniqueness of their living conditions and life experiences can push theoretical and empirical research forward in ways hitherto unexplored due to the focus of previous studies on groups that drive demographic patterns (majorities) and variable-based explanatory frameworks.

This is the case of domestic workers in LACar during the second half of the 20th century (Jelin, 1977; Tinsman, 1992). Women who performed household work for a private household during this period were a social and economic minority. The confluence of living circumstances through their life courses implied vulnerabilities of different kinds (Chanel \& Garcia Castro, 1989). First, as women, they suffered from gender inequality and gender-based violence and discrimination, which have a long history in LACar (García \& de Oliveira, 2011; World Health Organization, 2013). Second, as most of them were poor rural migrants, their bargaining power and empowerment were very limited once they arrived in cities. The same applies to domestic workers from urban backgrounds who typically came from impoverished urban areas (slums, fabellas, 
barrios de invasion) (Montgomery et al., 2003). Third, Afro-descendent and indigenous populations are overrepresented among domestic workers, making historical and institutional discrimination and exclusion against these groups an additional layer of oppression for domestic workers (Chanel \& Garcia Castro, 1989). Fourth, the lack of regulations and the low quality of law enforcement regarding their working conditions and rights made women vulnerable to exploitation by employers, particularly those living in the same household they worked for (Blofield \& Jokela, 2018; Moya, 2007).

\section{Context}

\section{Fertility decline in high inequality context}

The so-called fertility transition in LACar occurred relatively rapidly during the second half of the 20th century, starting around the 1960s and 1970s for most of the countries (Palloni, 1990). The total fertility rate (TFR) declined from six children per woman in 1950 to below three children by the end of the century virtually in all countries. However, the drop in the TFR was not homogeneous, neither within nor between countries (Guzmán et al., 2006). There are substantial differences across LACar countries regarding their economic structure and development, their populations' ethnic and migrant composition, and the family arrangements that stem from these social and economic structures, including fertility patterns (De Vos, 1995). Within countries, given the high and sustained levels of economic inequality, the heterogeneity in living conditions and family forms is also vast (Schkolnik \& Chackiel, 2004).

Although fertility declines in Brazil, Colombia, and Mexico were not identical, some similarities favor our research design. The decrease in the TFR started around the same period, and the overall trend of fertility decline across these three countries is similar (Guzmán et al., 2006, p. 532). Other similarities in the fertility decline of these nations include its sustained trend through periods of 
economic growth and crisis and the persistence of socioeconomic disparities (Adserà \& Menendez, 2011). This latter point is not surprising given the increasing trend of inequality brought about by the economic and social development that characterized the transition to market-based capitalist economies in LACar (Williamson, 2010).

LACar countries display economic inequality levels that are hard to exaggerate and are the material base of unequal power relations. Also, there are essential differences in the distribution of resources that underlies these high levels of inequality across countries. These differences also pertain to the subpopulations (including their size) that suffer the most from them. For example, the concentration of resources is more substantial in Brazil and Mexico than in Colombia. In 2010, the share of the income of the top $10 \%$ was $57 \%$ in Brazil, $53 \%$ in Colombia, and $59 \%$ in Mexico (The World Inequality Lab, 2020). Put simply, the rich are very rich and powerful, and the poor are very poor and powerless (i.e., subject to exploitation), particularly in Brazil and Mexico. These percentages map well on the Gini index for the income distribution of these three countries in the same year: 53.3 in Brazil, 49.7 in Colombia, and 47.2 in Mexico. This distributional inequality intersects with entrenched discrimination against the afro-descendent and indigenous populations in the three countries. The Black population is more numerous in Brazil and Colombia (above 10\% of the total population, vs. less than $3 \%$ in Mexico). In contrast, the percentage of people who identify themselves as indigenous is relatively more significant in Mexico (around 15\%). Notably, the feminization of poverty is a common trend in all three countries (Chant, 2013).

These similarities and differences in terms of fertility and inequality across these countries favor our comparative research design. They maximize differences in the potential explanatory factor of these fertility differentials, namely, structural inequality of life opportunities. Suppose the paradoxical fertility patterns among live-in domestic workers relate to social and economic 
inequality and exclusion. In that case, we should observe more considerable differences across social classes in Brazil. Besides, these three countries together account for more than 50\% of the total population in LACar with substantial differences in their population sizes: Brazil 200 million, Mexico 130 million, and Colombia 50 million, which further favors the generalizability of our results.

\section{Domestic work throughout the second half of the 20th century}

The socio-economic changes implied by the transition to a capitalist economy changed domestic work arrangements worldwide. Two of these changes relate directly to fertility-first, the feminization of domestic work, and second, the massive involvement of internal migrant populations. LACar countries were not the exception to this global dynamic. By the early 1960s, most domestic workers in the region were young migrant women of rural origin (Moya, 2007; L. S. Pinheiro et al., 2009).

Domestic work arrangements vary widely across and within LACar countries (Tokman, 2010). Despite the overall socio-economic vulnerability of the women who perform these tasks, domestic workers are not a homogenous group. A myriad of kinship, distant-kinship, and acquaintance arrangements exist within households that host, hire, or have a domestic worker as a co-resident. There is a clear correlation between the type of arrangement (employment condition, live-in, liveout) and the class status of the employer/host family. For high-class families in the mid-twenty century, hiring domestic workers was not only a possibility given their resources but a class marker and element of distinction. In more contemporary contexts, and to some extent, thanks to the increasing (still insufficient) regulations to protect the rights of domestic workers, hiring live-in domestic workers became less affordable. Only very affluent families can pay for these types of services (Blofield \& Jokela, 2018). Some families employ live-in domestic workers temporarily, 
while the children need daily adult supervision and the parents (most pressingly the mother) need to free their time to work or acquire higher education. Instead, live-out domestic workers have increasingly become an option. Electronic appliances reduce the burden of household chores (e.g., laundry machines), therefore reducing the demand for 24/7 services (Chanel \& Garcia Castro, 1989, Chapter 1).

Among low-class families, live-in domestic work arrangements occur for very distinct reasons, i.e., not as a marker of class status and not as a way of liberating the time of the mistress for pursuing higher education or professional careers during childbearing years. Instead, live-in domestic arrangements could occur among distant family members or family acquaintances who live in urban areas and are willing to receive a young woman as a "helper" from a rural household. In exchange for her help, the urban family offers shelter and access to urban life's potential benefits, including part-time, nocturnal, or weekend-based schooling. In this context, a domestic worker in a low-class household could potentially reduce the burden of household chores. However, it could also become a burden as the family still needs to care about the young woman (Chanel \& Garcia Castro, 1989, sec. II).

In terms of socio-economic and demographic variation, country-specific migration streams differ across countries, making the ethnic composition of this group specific to each country and specific regions within countries (Portes, 1989; Tokman, 2010). This variation implies that these groups are very heterogeneous and that their measurement is not straightforward. For example, in Brazil, besides the rural-urban migration movements, poverty conditions also triggered massive migration waves from the North-east to more developed cities in the South-east, to the point that the Portuguese word for people from this region 'nordestino' became a synonym for domestic workers (Moya, 2007). Most of these migrant women are black (L. Pinheiro et al., 2019). In the case of 
Colombia, both economically-driven and violence-driven/forced displacement have primarily been responsible for the increasing number of young rural populations arriving in intermediate and large cities (Ibáñez, 2009). Big and mid-size cities all over the country became nodes of reception of rural migrants from their surrounding rural areas. In Mexico, the unequal development of labor markets, the low prices of agricultural products, and the high demand for low-skilled jobs in cities in the 1950s incentivized migration from rural to urban areas (Donato et al., 2010). The need for marriable women for low-skilled workers and a long-standing tradition of living-in domestic workers (sirvientas or nodrizas) created a market for women from rural places.

Live-in and live-out arrangements have coexisted in these three countries. The former arrangements were more common from the 1950s to the 1990s. By that time, typical houses of middle- and upper-class families included an additional small room called "el cuarto del servicio" or "quarto de serviço/empregada," (service/maids' room), typically located far from other rooms, next to the patio in houses, or beside the kitchen in apartments. This particular form of co-residence has ambivalent consequences for the domestic workers. On the one hand, it implies physical proximity and daily interactions, which, in some cases, generate emotional bonds, particularly with children (Brites, 2007; Colen, 1995). On the other hand, it exposes women to all kinds of abuses as they are isolated and practically 'at work' on a $24 / 7$ basis. Physical control and permanent surveillance are landmarks of unbalanced power relations between employers and live-in domestic workers. In more recent years, live-out arrangements have become more prevalent than live-in due to multiple factors, including decreasing labor supply, lower and overall declining fertility, increasing (yet insufficient) regulations to this type of work, and the rise of substitute economic activities provided by the informal sector (Portes \& Hoffman, 2003). 


\section{Data and methods}

We use 12 census samples from the Integrated Public Use Microdata Series, International (Minnesota Population Center, 2020), four for each country, as seen in Table 1.

Table 1. Sample size (in thousands) by country and place of residence, and for domestic live-in and live-out workers in Brazil, Colombia, and Mexico.

\begin{tabular}{|c|c|c|c|c|c|c|c|}
\hline Country & $\begin{array}{c}\text { Census } \\
\text { year }\end{array}$ & $\begin{array}{l}\text { Large } \\
\text { cities }\end{array}$ & $\begin{array}{l}\text { Urban } \\
\text { areas }\end{array}$ & $\begin{array}{l}\text { Rural } \\
\text { areas }\end{array}$ & $\begin{array}{c}\text { Live-in } \\
\text { domestic } \\
\text { workers }\end{array}$ & $\begin{array}{l}\text { Live-out } \\
\text { domestic } \\
\text { workers }\end{array}$ & $\begin{array}{c}\text { \% urban } \\
\text { among live- } \\
\text { in d.w. }\end{array}$ \\
\hline \multirow[t]{5}{*}{ Brazil } & 1980 & 889 & 4,116 & 2,077 & 180 & 305 & 94.6 \\
\hline & 1991 & 403 & 2,636 & 1,081 & 66 & 258 & 89.8 \\
\hline & 2000 & 442 & 3,592 & 1,082 & 42 & 435 & 70.7 \\
\hline & 2010 & 232 & 3,932 & 1,119 & 16 & 443 & 94.0 \\
\hline & Subtotal & 1,967 & 14,276 & 5,359 & 304 & 1,442 & \\
\hline \multirow[t]{5}{*}{ Colombia } & 1973 & 90 & 216 & 150 & 25 & 8 & 92.7 \\
\hline & 1985 & 158 & 353 & 174 & 27 & 22 & 73.5 \\
\hline & 1993 & 195 & 468 & 200 & 22 & 11 & 67.0 \\
\hline & 2005 & 87 & 551 & 380 & 8 & 11 & 91.4 \\
\hline & Subtotal & 530 & 1,589 & 904 & 83 & 51 & \\
\hline \multirow[t]{5}{*}{ Mexico } & 1970 & 16 & 47 & 42 & 2 & 3 & 90.6 \\
\hline & 1990 & 204 & 1,354 & 520 & 23 & 37 & 79.1 \\
\hline & 2000 & 163 & 1,459 & 945 & 22 & 103 & 60.2 \\
\hline & 2010 & 72 & 1,591 & 1,421 & 7 & 106 & 94.4 \\
\hline & Subtotal & 455 & 4,450 & 2,927 & 55 & 249 & \\
\hline \multicolumn{2}{|c|}{ Total } & 2,952 & 20,316 & 9,190 & 442 & 1,742 & 34,641 \\
\hline \multicolumn{2}{|c|}{ Percentage } & 8.5 & 58.6 & 26.5 & 1.3 & 5.0 & 100 \\
\hline
\end{tabular}

Note: samples include women ages 15 to 49 and were extracted from IPUMS-I. The \% urban includes domestic live-in workers in large cities and other urban areas.

We analyze data for more than 34.6 million women, ages 15 to 49 , organized into five groups. The first three groups are mutually exclusive geographical areas because geography is a crucial axis of variation of fertility and socioeconomic status in LACar. The concentration of resources and economic development in large cities makes it important to distinguish them from other urban areas, which sometimes look more akin to rural in terms of public services and infrastructure 
(Montgomery et al., 2003). This category includes Sao Paulo and Rio de Janeiro in Brazil, Bogota and Medellin in Colombia, and Mexico City and Guadalajara in Mexico.

At the other end of the development spectrum, rural areas in these three countries have historically suffered from underdevelopment, lack of state presence, and violence, particularly in Mexico and Colombia (Alegre, 2003; Mercado, 2014). In addition, these geographical areas represent the typical origin (rural) and destination (large cities and urban areas) of most domestic workers, as shown by the last column of Table 1 .

The following two groups are women who perform domestic tasks for a private household differe nt from their own in live-in and live-out arrangements (see details below). Domestic duties include cooking, washing dishes and clothes, cleaning, and caring for the children and elderly. Live-in domestic workers co-reside with the household members they work for. Live-out domestic workers live in a separate dwelling (i.e., with their own household). These women can work for more than one household, part-time or per hour.

Besides providing adequate sample sizes for statistical analyses, these samples are appropriate to examine the role of domestic work on fertility in LACar because they have an extended temporal scope and cover ample cultural and population-wise spectrums. These are all desirable characteristics when investigating large-scale fertility changes (Portes, 2006). In terms of temporal coverage, our samples include the 1920 to 1950 birth cohorts. These cohorts experienced a confluence of socioeconomic changes, including urbanization, educational expansion, fertility decline, and economic growth until 1980. This flourishing period was followed by economic deceleration and rising income inequality until the early 2000s (Bethell, 1998; Sánchez-Ancochea, 2021). In terms of culture, the colonial legacy of these three nations differs substantially (Quijano, 
2000). This cultural diversity is reflected in the differences in the national languages, ethnic composition, and levels and types of economic inequality of these three countries.

\section{Identifying live-in and live-out domestic workers}

To identify domestic workers and their mode of work (live-in or live-out) in two steps. First, we combine information on the position at work (variable CLASSWK), occupation (variable OCC), and industry (variable IND) to identify all women performing household/domestic tasks for a private household, regardless of their work arrangement. Because data availability and collection methodologies differ across countries and over time, we follow country-year-specific strategies. For Brazil, we use the variable describing the occupation of the respondent. We include as domestic workers all women whose occupational status implies performing household chores, on a full-time or part-time basis, for a private household. For Colombia, we use the variable class of workers (CLASSWK). This variable has one category for "domestic workers." For Mexico, we combine information on respondent's occupation and industry to include all women performing the same type of tasks for a private household different from their own.

Next, we check the relationship to the household head of all women identified as domestic workers. We assume that those not related to the household head by kinship (e.g., daughter, niece, grandchild, sister) or the law (spouse, partner, daughter-in-law, etc.), are live-in domestic workers; all the others are classified as live-out domestic workers. Hence, live-in domestic workers are those reported as "domestic employee," "relative of employee (not classified elsewhere)," "spouse of a servant," "child of a servant," "other relative of a servant," and "non-relative, non-classified elsewhere."

This assumption is necessary given the tendency to misreport live-in domestic workers (Levinson \& Langer, 2010). Families were often unwilling to declare live-in domestic workers because they 
fear social judgment and penalties from the authorities given the irregularity of working conditions of these women. Hence, live-in domestic workers were often reported either as living somewhere else or as family members, though they did not have a kinship relationship with the household head. Our assumption partially alleviates the first type of misreporting, but it does not address the second. This is the best possible measurement strategy with the data at hand.

\section{Methodological approach}

Our approach is comparative and purely descriptive. For each of the groups and census rounds shown in Table 1, we estimate a series of age-specific measures such as the mean number of children ever born (cumulative fertility rate, herein), average years of schooling, prevalence of marriage, unions, and divorce, and prevalence of domestic migration (defined as a change of residence in the five years preceding the census). These measures capture the main features of LACar societal and economic transformation and the family change that occurred during the analysis period.

The significance of these comparisons relies on two aspects. First, the use of several census rounds allows us to overcome the lack of longitudinal data, and permits us to examine fertility change and differentials from a life course and historically-rooted perspective. Second, the main differences among the groups we study relate to their social position and the power relations stemming from these differential locations in the social space. This comparative strategy allows to incorporate power relations into the study of fertility and accounts for the differential value of reproduction associated with different groups of women (Colen, 1995).

To assess the role of live-in domestic workers on the fertility of their mistress, we compare the cumulative fertility rates between women who live in households with and without live-in domestic workers (i.e., between mistress and non-employers). To further capture differential 
power dynamics and the significance of domestic work for the reproduction of higher-class households, we stratify these comparisons by women's educational attainment. A positive association between having a domestic worker at home and fertility would imply that domestic workers contribute to the reproduction of their employers as portrayed in all the movies, soap operas, and literary accounts on the relationships between domestic workers and household members. This way, our methods recast fertility change and differentials as embedded in power and class relations, adding a layer of complexity to explanations focused on individual choice.

\section{Results}

The significance of domestic work as a concrete working condition, particularly in live-in arrangements, must be considered from a life course perspective. Women who start working as domestic workers have lower educational and occupational mobility chances due to a series of cumulative disadvantages related to their subordinate position concerning their employers. This is evident in the age profiles displayed in Figure 1. We separate the oldest (Panel A) age profiles and the most recent census rounds (Panel B) to examine changes and continuities over time across countries.

In the oldest census rounds (i.e., in the 1970s and 1980s), at least $15 \%$ of live-in domestic workers are below the legal age of majority (i.e., 18 years of age), and more than $50 \%$ are below age 25 . By the 2000s and 2010s, the proportion of domestic workers below age 18 declined dramatically ( $<5 \%$ in all countries) and the overall age profile became older than that of the 1970s and 1980s. However, the age profile of live-in domestic workers is younger than the age profile of women in large cities, urban areas, and rural areas, meaning that despite fundamental changes in live-in domestic work arrangements, this minority group comprises primarily young women. Moreover, the age groups at which the proportion of live-in domestic workers peaks have not changed over 
time. The modal age groups for live-in domestic workers include always 18 years of age, which could be due to women's increased capacity to leave their parental household once they reach majority.

Figure 1. Age profiles by country and place of residence, and for domestic live-in and live-out workers.

Panel A: Brazil 1980, Colombia 1973, Mexico 1970.
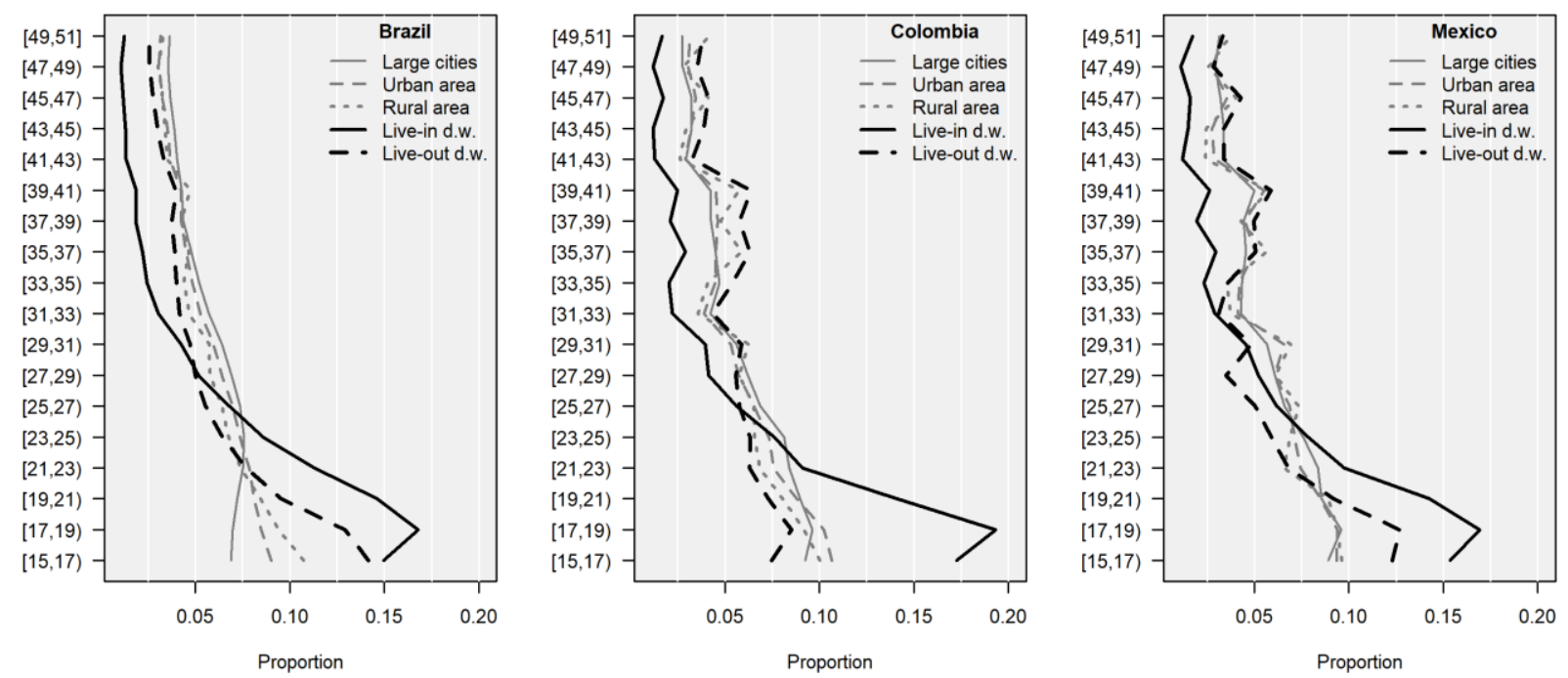

Panel B: Brazil 2010, Colombia 2005, Mexico 2010
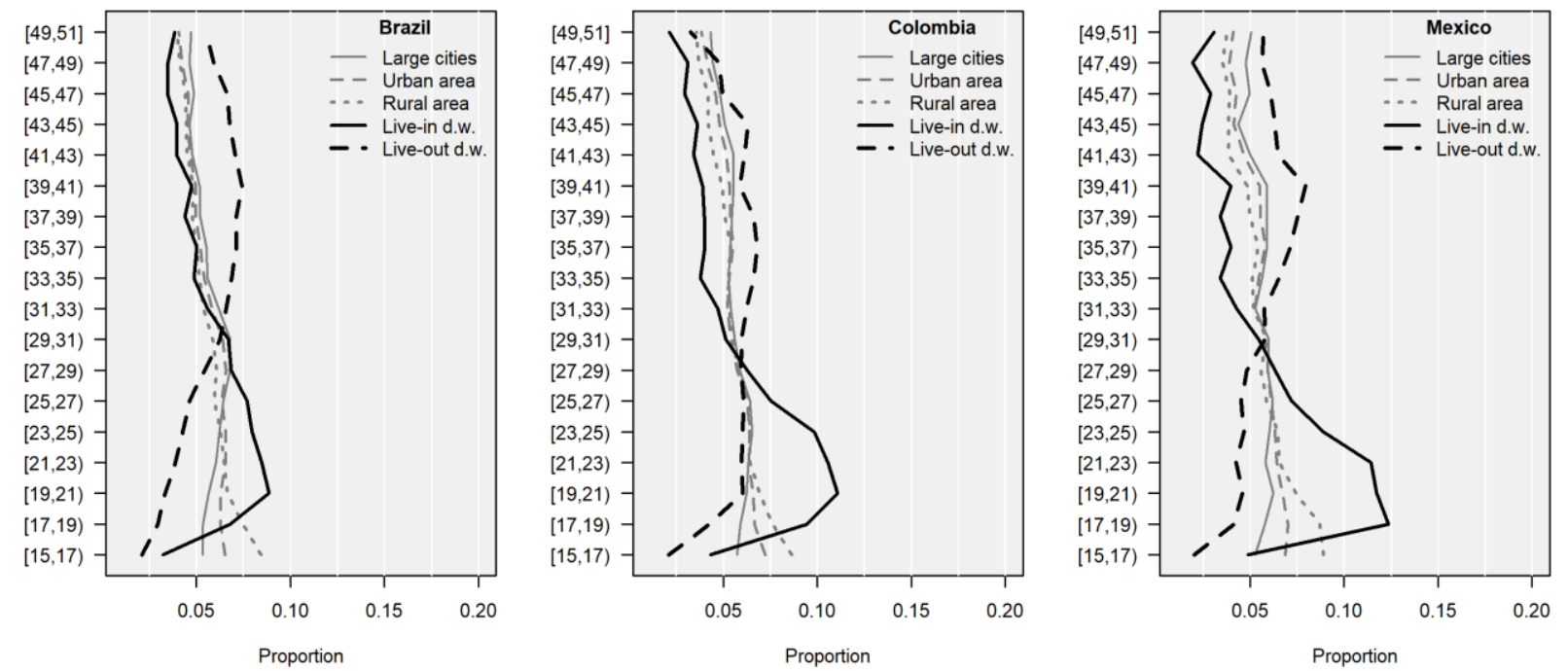

Note: Age profiles for the other census rounds are reported in Figure A1 and are more similar to Panel A than Panel B. 
At the top-end of the reproductive ages, the proportion of live-in domestic workers is low. Although it is higher in the 2000s/2010s than in the 1970s/1980s, the share of women in each age group after age 35 is below 5\%. After this age, this small proportion of live-in domestic workers is related to the fact that most live-in domestic workers change their occupation once they can afford to live by themselves and form their households. The group of them who remain as live-in domestic workers after age 40 is therefore very selected. Despite changes over time, these two patterns: high shares at the beginning and low shares at the end of the reproductive period, are observed at the two points in time and underline the need to understand the relationship between fertility and domestic work from a life course perspective. The mid-period census rounds (i.e., 1985 to 2000) depict patterns that resemble more Panel A than Panel B (see Figure A1), meaning the very young profile of live-in domestic workers was a feature of most of the second half of the 20th century.

Besides the very young age profile of live-in domestic workers, two interrelated patterns in Figure 1 are worth mentioning. First, differences in the age structure across geographical areas persist over time and are more significant at younger than older ages and in more recent censuses compared to older ones. In general, rural and urban areas have higher shares of women below age 20 than large cities. This is the result of long-lasting fertility differentials across these three areas. These differences are essential because domestic workers are typically migrant women who move from rural to urban areas, i.e., from high to low fertility contexts.

Second, there is a crossover between the age structure of live-in and live-out domestic workers in all the census rounds. A hump follows this crossover in the age profile of live-out domestic workers (particularly marked in Panel B) which is consistent with the fact that, over time, domestic workers transit from live-in to live-out work arrangements. Although this crossover is apparent in all three 
countries, it occurs slightly earlier in Colombia in 1973 than in Brazil in 1980 and Mexico in 1970, meaning that the transition out of live-in arrangements takes place later in the two latter countries compared to Colombia. In other words, live-in domestic service tends to last longer, and live-in domestic workers are slightly older in the two largest nations of LACar compared to Colombia. Over time, this crossover moves up in the age groups, potentially due to the reduction in the share of both live-in and live-out domestic workers below age 25 .

\section{The paradox of lower fertility among live-in domestic workers}

Table 2 shows the age-specific cumulative fertility rates for women in each country's oldest and most recent census rounds. Because censuses are separated by about 30 years, women in the 15 to 25 age group in the first censuses were born the same years as women in the 45 to 55 age group in the last census (this is less the case in Mexico because the oldest and most recent censuses are separated by 40 years). If we put the 1980 Mexican census our conclusions will be the same.

The cumulative fertility rate of the last age group summarizes the well-documented process of fertility decline during the second half of the 20th century in LACar countries and the persistence of geographical gaps in family size. In large cities, the average number of children per woman declined from 3.3 to 1.8 in Brazil, 5.5 to 2.4 in Colombia, and 5.3 to 2.3 in Mexico. These same figures for rural areas were 6.6 to 3.7 (Brazil), 7.4 to 4.3 (Colombia), and 6.9 to 4.7 children (Mexico). Note the strong convergence in large cities where the cumulative complete fertility rate hovers around two according to the most recent censuses, versus the sustained heterogeneity in rural areas ranging from 3.7 to 4.7 children.

In this context of widespread and unequal fertility decline, the cumulative fertility among live-in domestic workers is the lowest of all groups; this is true for all ages in all the three countries. This persistently low fertility means that, compared to all other women, fertility among live-in domestic 
workers starts later, displays lower intensity during adulthood, and results in lower completed fertility by the end of the reproductive period. Fertility decline over time is also less pronounced among live-in domestic workers than the other women, to the point that changes over time in completed fertility (i.e., age group 45 to 55) are not statistically significant.

Table 2. Age-specific cumulative fertility rates by country and place of residence, and for domestic live-in and live-out workers.

\begin{tabular}{|c|c|c|c|c|c|c|c|c|c|c|}
\hline \multirow{2}{*}{$\begin{array}{c}\begin{array}{c}\text { Country and } \\
\text { age group }\end{array} \\
\text { Brazil } \\
\end{array}$} & \multicolumn{2}{|c|}{ Large cities } & \multicolumn{2}{|c|}{ Urban are as } & \multicolumn{2}{|c|}{ Rural are as } & \multicolumn{2}{|c|}{$\begin{array}{c}\text { Live-in } \\
\text { domestic } \\
\text { workers }\end{array}$} & \multicolumn{2}{|c|}{$\begin{array}{c}\text { Live-out } \\
\text { domestic } \\
\text { workers }\end{array}$} \\
\hline & 1980 & 2010 & 1980 & 2010 & 1980 & 2010 & 1980 & 2010 & 1980 & 2010 \\
\hline$[15,25)$ & $\begin{array}{r}0.4 \\
(0.00)\end{array}$ & $\begin{array}{r}0.3 \\
(0.00)\end{array}$ & $\begin{array}{r}0.5 \\
(0.00)\end{array}$ & $\begin{array}{r}0.3 \\
(0.00)\end{array}$ & $\begin{array}{r}0.7 \\
(0.00)\end{array}$ & $\begin{array}{r}0.5 \\
(0.00)\end{array}$ & $\begin{array}{r}0.1 \\
(0.00)\end{array}$ & $\begin{array}{r}0.2 \\
(0.01)\end{array}$ & $\begin{array}{r}0.3 \\
(0.00)\end{array}$ & $\begin{array}{r}0.6 \\
(0.00)\end{array}$ \\
\hline$[25,35)$ & $\begin{array}{r}1.7 \\
(0.00)\end{array}$ & $\begin{array}{r}0.9 \\
(0.00)\end{array}$ & $\begin{array}{r}2.4 \\
(0.00)\end{array}$ & $\begin{array}{r}1.3 \\
(0.00)\end{array}$ & $\begin{array}{r}3.4 \\
(0.00)\end{array}$ & $\begin{array}{r}2.0 \\
(0.00)\end{array}$ & $\begin{array}{r}0.7 \\
(0.01)\end{array}$ & $\begin{array}{r}0.6 \\
(0.02)\end{array}$ & $\begin{array}{r}2.3 \\
(0.01)\end{array}$ & $\begin{array}{r}1.8 \\
(0.00)\end{array}$ \\
\hline$[35,45)$ & $\begin{array}{r}2.9 \\
(0.01)\end{array}$ & $\begin{array}{r}1.6 \\
(0.01)\end{array}$ & $\begin{array}{r}4.4 \\
(0.00)\end{array}$ & $\begin{array}{r}2.0 \\
(0.00)\end{array}$ & $\begin{array}{r}5.9 \\
(0.01)\end{array}$ & $\begin{array}{r}3.0 \\
(0.00)\end{array}$ & $\begin{array}{r}1.3 \\
(0.02)\end{array}$ & $\begin{array}{r}1.1 \\
(0.03)\end{array}$ & $\begin{array}{r}4.3 \\
(0.01)\end{array}$ & $\begin{array}{r}2.4 \\
(0.00)\end{array}$ \\
\hline$[45,55]$ & $\begin{array}{r}3.3 \\
(0.01)\end{array}$ & $\begin{array}{r}1.8 \\
(0.01)\end{array}$ & $\begin{array}{r}5.3 \\
(0.01)\end{array}$ & $\begin{array}{r}2.4 \\
(0.00)\end{array}$ & $\begin{array}{r}6.6 \\
(0.01)\end{array}$ & $\begin{array}{r}3.7 \\
(0.01)\end{array}$ & $\begin{array}{r}1.5 \\
(0.03)\end{array}$ & $\begin{array}{r}1.4 \\
(0.05)\end{array}$ & $\begin{array}{r}4.9 \\
(0.02)\end{array}$ & $\begin{array}{r}2.7 \\
(0.01)\end{array}$ \\
\hline Colombia & 1973 & 2005 & 1973 & 2005 & 1973 & 2005 & 1973 & 2005 & 1973 & 2005 \\
\hline$[15,25)$ & $\begin{array}{r}0.6 \\
(0.01)\end{array}$ & $\begin{array}{r}0.4 \\
(0.01)\end{array}$ & $\begin{array}{r}0.8 \\
(0.00)\end{array}$ & $\begin{array}{r}0.4 \\
(0.00)\end{array}$ & $\begin{array}{r}1.2 \\
(0.01)\end{array}$ & $\begin{array}{r}0.7 \\
(0.00)\end{array}$ & $\begin{array}{r}0.3 \\
(0.01)\end{array}$ & $\begin{array}{r}0.2 \\
(0.01)\end{array}$ & $\begin{array}{r}1.0 \\
(0.03)\end{array}$ & $\begin{array}{r}0.7 \\
(0.03)\end{array}$ \\
\hline$[25,35)$ & $\begin{array}{r}2.6 \\
(0.01)\end{array}$ & $\begin{array}{r}1.3 \\
(0.01)\end{array}$ & $\begin{array}{r}3.3 \\
(0.01)\end{array}$ & $\begin{array}{r}1.6 \\
(0.01)\end{array}$ & $\begin{array}{r}4.4 \\
(0.01)\end{array}$ & $\begin{array}{r}2.4 \\
(0.01)\end{array}$ & $\begin{array}{r}1.4 \\
(0.03)\end{array}$ & $\begin{array}{r}1.1 \\
(0.04)\end{array}$ & $\begin{array}{r}3.6 \\
(0.06)\end{array}$ & $\begin{array}{r}2.1 \\
(0.04)\end{array}$ \\
\hline$[35,45)$ & $\begin{array}{r}4.6 \\
(0.03)\end{array}$ & $\begin{array}{r}2.1 \\
(0.01)\end{array}$ & $\begin{array}{r}5.6 \\
(0.02)\end{array}$ & $\begin{array}{r}2.5 \\
(0.01)\end{array}$ & $\begin{array}{r}6.9 \\
(0.02)\end{array}$ & $\begin{array}{r}3.5 \\
(0.01)\end{array}$ & $\begin{array}{r}2.3 \\
(0.06)\end{array}$ & $\begin{array}{r}1.7 \\
(0.06)\end{array}$ & $\begin{array}{r}5.4 \\
(0.08)\end{array}$ & $\begin{array}{r}2.9 \\
(0.05)\end{array}$ \\
\hline$[45,55]$ & $\begin{array}{r}5.5 \\
(0.05) \\
\end{array}$ & $\begin{array}{r}2.4 \\
(0.02)\end{array}$ & $\begin{array}{r}6.2 \\
(0.03)\end{array}$ & $\begin{array}{r}2.9 \\
(0.01)\end{array}$ & $\begin{array}{r}7.4 \\
(0.03)\end{array}$ & $\begin{array}{r}4.3 \\
(0.02) \\
\end{array}$ & $\begin{array}{r}2.5 \\
(0.10) \\
\end{array}$ & $\begin{array}{r}2.0 \\
(0.10)\end{array}$ & $\begin{array}{r}6.0 \\
(0.15) \\
\end{array}$ & $\begin{array}{r}3.5 \\
(0.09)\end{array}$ \\
\hline Mexico & 1970 & 2010 & 1970 & 2010 & 1970 & 2010 & 1970 & 2010 & 1970 & 2010 \\
\hline$[15,25)$ & $\begin{array}{r}0.6 \\
(0.02)\end{array}$ & $\begin{array}{r}0.3 \\
(0.01)\end{array}$ & $\begin{array}{r}0.7 \\
(0.01)\end{array}$ & $\begin{array}{r}0.4 \\
(0.00)\end{array}$ & $\begin{array}{r}0.9 \\
(0.01)\end{array}$ & $\begin{array}{r}0.5 \\
(0.00)\end{array}$ & $\begin{array}{r}0.3 \\
(0.02)\end{array}$ & $\begin{array}{r}0.1 \\
(0.01)\end{array}$ & $\begin{array}{r}0.3 \\
(0.03)\end{array}$ & $\begin{array}{r}0.5 \\
(0.01)\end{array}$ \\
\hline$[25,35)$ & $\begin{array}{r}3.0 \\
(0.04)\end{array}$ & $\begin{array}{r}1.1 \\
(0.01)\end{array}$ & $\begin{array}{r}3.6 \\
(0.03)\end{array}$ & $\begin{array}{r}1.7 \\
(0.00)\end{array}$ & $\begin{array}{r}4.2 \\
(0.03)\end{array}$ & $\begin{array}{r}2.3 \\
(0.01)\end{array}$ & $\begin{array}{r}1.7 \\
(0.10)\end{array}$ & $\begin{array}{r}0.7 \\
(0.04)\end{array}$ & $\begin{array}{r}3.1 \\
(0.12)\end{array}$ & $\begin{array}{r}2.0 \\
(0.02)\end{array}$ \\
\hline$[35,45)$ & $\begin{array}{r}5.2 \\
(0.07)\end{array}$ & $\begin{array}{r}1.9 \\
(0.02)\end{array}$ & $\begin{array}{r}5.9 \\
(0.04)\end{array}$ & $\begin{array}{r}2.6 \\
(0.00)\end{array}$ & $\begin{array}{r}6.5 \\
(0.04)\end{array}$ & $\begin{array}{r}3.6 \\
(0.01)\end{array}$ & $\begin{array}{r}3.0 \\
(0.21)\end{array}$ & $\begin{array}{r}1.3 \\
(0.07)\end{array}$ & $\begin{array}{r}5.5 \\
(0.16)\end{array}$ & $\begin{array}{r}3.0 \\
(0.02)\end{array}$ \\
\hline$[45,55]$ & $\begin{array}{r}5.3 \\
(0.11)\end{array}$ & $\begin{array}{r}2.3 \\
(0.02)\end{array}$ & $\begin{array}{r}6.0 \\
(0.07)\end{array}$ & $\begin{array}{r}3.1 \\
(0.01)\end{array}$ & $\begin{array}{r}6.9 \\
(0.07)\end{array}$ & $\begin{array}{r}4.7 \\
(0.02)\end{array}$ & $\begin{array}{r}3.3 \\
(0.33)\end{array}$ & $\begin{array}{r}1.9 \\
(0.13)\end{array}$ & $\begin{array}{r}5.6 \\
(0.26)\end{array}$ & $\begin{array}{r}3.6 \\
(0.03)\end{array}$ \\
\hline
\end{tabular}

Note: Standard errors in parenthesis.

Given the magnitude of the fertility declines among other groups of women, especially in completed fertility in all geographical areas (e.g., more than $50 \%$ decline, except in Colombian and Mexican rural regions), the fact that fertility among live-in domestic workers did not decline 
substantially indicates that the material conditions affecting fertility decisions (or realizations) of these minorities did not change throughout the so-called fertility transition. In addition, and as a result of these low and unchanging fertility rates, the age-specific fertility patterns of live-in domestic workers in the last census rounds resemble those of women in large cities, a group of women with whom they (the live-in domestic workers) have very little, if anything, in common, socioeconomically speaking (see more on this below).

Despite these similar overarching patterns among live-in domestic workers across countries, there are significant nuances in their fertility schedules. First, Brazil stands out by the very low fertility of live-in domestic workers. By age 35 live-in domestic workers in Brazil had, on average, slightly more than one child in 1980 and 2010; indeed, more than $50 \%$ of these women are childless (Table A1). These figures contrast with the proportion of child less women in other groups at the same age: $14 \%, 10 \%$ and $8 \%$ in large cities, urban areas, and rural areas in 1980 , respectively. Due to fertility decline and postponement, these latter figures are higher in 2010 than in 1980, but none surpasses $50 \%$.

Second, the fertility schedules of live-in domestic workers in Colombia suggest a stopping behavior after age 35. The cumulative fertility rate of the last two age groups is very similar 2.3 2.5 in 1973 and 1.7-2.0 in 2005 meaning that there are very few additional children born from adulthood to the end of the reproductive period among this group of women. Consistently, the proportion of childless women by age 45 among Colombian live-in domestic workers is above $20 \%$ (Table A1); which is more than twice as much as the proportion of childless women in all other groups. Third, in Mexico, the relative increase in the number of children between the last two age groups is high in 2010, with around 0.6 additional children, on average. This means that, within the low fertility pattern of live-in domestic workers in Mexico, late fertility is not 
uncommon. Yet, the proportion of live-in domestic workers who did not have children by age 45 is above $25 \%$ in both censuses. All these nuances point to the fact that live-in domestic services are not identical across countries, despite similarities in the general patterns.

Because live-in domestic workers change occupations over time and our data is cross-sectional, these descriptions should be taken with care and complemented with examining patterns among live-out domestic workers. Assuming, based on the literature, that some of the live-in domestic workers become live-out domestic workers by early adulthood (as suggested by the crossovers in Figure 1), the fertility schedule of live-out domestic workers complements previous descriptions. Live-out domestic workers display higher fertility rates than live-in domestic workers but lower fertility than women in rural areas.

From the standpoint of modernity (urbanization and educational expansion) as the primary driver of fertility decline, the fertility patterns of live-in domestic workers, in particular their resemblance with of those of women in large cities, are hard to reconcile with their lower levels of educational attainment, one of the main factors of low fertility in LACar. According to Table 3, live-in domestic workers display very low mean years of schooling compared to women living in large cities and urban areas. They are slightly better off than women in rural areas and live-out domestic workers, however, the size of the difference in years of schooling cannot explain the lower fertility rates of live-in domestic workers. This is because the educational expansion did not benefit all women to the same extent. What became compulsory and "universal" was primary education and the quality differential between public and private (rural vs. urban) schools remained (SánchezAncochea, 2021).

For example, among the birth cohort who lived throughout sharp fertility declines (1960-1970) and completed their fertility in the 2000s and 2010s (age group 45 to 55), the years of schooling 
of live-in domestic workers are below six years: 4 in Brazil, 4.7 in Colombia, and 5.5 in Mexico. These figures are in sharp contrast with the 8.5, 9.2, and 10.8 mean years of schooling of the same cohorts of women in large Brazilian, Colombian, and Mexican cities, respectively.

Table 3. Age-specific mean years of schooling by country and place of residence and for domestic live-in and live-out workers.

\begin{tabular}{|c|c|c|c|c|c|c|c|c|c|c|}
\hline \multirow{2}{*}{$\begin{array}{c}\text { Country and } \\
\text { age group } \\
\text { Brazil }\end{array}$} & \multicolumn{2}{|c|}{ Large cities } & \multicolumn{2}{|c|}{ Urban are as } & \multicolumn{2}{|c|}{ Rural areas } & \multicolumn{2}{|c|}{$\begin{array}{c}\text { Live-in } \\
\text { domes tic } \\
\text { workers }\end{array}$} & \multicolumn{2}{|c|}{$\begin{array}{l}\text { Live-out } \\
\text { domes tic } \\
\text { workers }\end{array}$} \\
\hline & 1980 & 2000 & 1980 & 2000 & 1980 & 2000 & 1980 & 2000 & 1980 & 2000 \\
\hline$[15,25)$ & $\begin{array}{r}7.2 \\
(0.01)\end{array}$ & $\begin{array}{r}9.0 \\
(0.01)\end{array}$ & $\begin{array}{r}6.1 \\
(0.00)\end{array}$ & $\begin{array}{r}8.0 \\
(0.00)\end{array}$ & $\begin{array}{r}2.6 \\
(0.00)\end{array}$ & $\begin{array}{r}5.1 \\
(0.01)\end{array}$ & $\begin{array}{r}3.3 \\
(0.01)\end{array}$ & $\begin{array}{r}5.9 \\
(0.02)\end{array}$ & $\begin{array}{r}3.7 \\
(0.01)\end{array}$ & $\begin{array}{r}6.2 \\
(0.01)\end{array}$ \\
\hline$[25,35)$ & $\begin{array}{r}7.1 \\
(0.01)\end{array}$ & $\begin{array}{r}9.7 \\
(0.01)\end{array}$ & $\begin{array}{r}5.6 \\
(0.00)\end{array}$ & $\begin{array}{r}8.1 \\
(0.00)\end{array}$ & $\begin{array}{r}2.0 \\
(0.00)\end{array}$ & $\begin{array}{r}4.3 \\
(0.01)\end{array}$ & $\begin{array}{r}3.0 \\
(0.01)\end{array}$ & $\begin{array}{r}5.9 \\
(0.03)\end{array}$ & $\begin{array}{r}2.8 \\
(0.01)\end{array}$ & $\begin{array}{r}5.3 \\
(0.01)\end{array}$ \\
\hline$[35,45)$ & $\begin{array}{r}5.7 \\
(0.01)\end{array}$ & $\begin{array}{r}9.3 \\
(0.01)\end{array}$ & $\begin{array}{r}4.0 \\
(0.00)\end{array}$ & $\begin{array}{r}7.4 \\
(0.01)\end{array}$ & $\begin{array}{r}1.3 \\
(0.00)\end{array}$ & $\begin{array}{r}3.5 \\
(0.01)\end{array}$ & $\begin{array}{r}2.2 \\
(0.02)\end{array}$ & $\begin{array}{r}4.8 \\
(0.05)\end{array}$ & $\begin{array}{r}2.0 \\
(0.01)\end{array}$ & $\begin{array}{r}4.4 \\
(0.01)\end{array}$ \\
\hline$[45,55]$ & $\begin{array}{r}4.9 \\
(0.01)\end{array}$ & $\begin{array}{r}8.5 \\
(0.02)\end{array}$ & $\begin{array}{r}3.2 \\
(0.01)\end{array}$ & $\begin{array}{r}6.4 \\
(0.01)\end{array}$ & $\begin{array}{r}1.0 \\
(0.00) \\
\end{array}$ & $\begin{array}{r}2.6 \\
(0.01) \\
\end{array}$ & $\begin{array}{r}1.8 \\
(0.03) \\
\end{array}$ & $\begin{array}{r}4.0 \\
(0.08) \\
\end{array}$ & $\begin{array}{r}1.6 \\
(0.01) \\
\end{array}$ & $\begin{array}{r}3.6 \\
(0.01) \\
\end{array}$ \\
\hline Colombia & 1973 & 2005 & 1973 & 2005 & 1973 & 2005 & 1973 & 2005 & 1973 & 2005 \\
\hline$[15,25)$ & $\begin{array}{r}6.6 \\
(0.02)\end{array}$ & $\begin{array}{r}10.5 \\
(0.02)\end{array}$ & $\begin{array}{r}5.5 \\
(0.01)\end{array}$ & $\begin{array}{r}9.7 \\
(0.01)\end{array}$ & $\begin{array}{r}2.8 \\
(0.01)\end{array}$ & $\begin{array}{r}6.6 \\
(0.01)\end{array}$ & $\begin{array}{r}2.9 \\
(0.02)\end{array}$ & $\begin{array}{r}7.7 \\
(0.08)\end{array}$ & $\begin{array}{r}2.8 \\
(0.04)\end{array}$ & $\begin{array}{r}6.9 \\
(0.11)\end{array}$ \\
\hline$[25,35)$ & $\begin{array}{r}6.0 \\
(0.02)\end{array}$ & $\begin{array}{r}11.1 \\
(0.03)\end{array}$ & $\begin{array}{r}4.5 \\
(0.01)\end{array}$ & $\begin{array}{r}9.8 \\
(0.02)\end{array}$ & $\begin{array}{r}2.1 \\
(0.01)\end{array}$ & $\begin{array}{r}5.5 \\
(0.02)\end{array}$ & $\begin{array}{r}2.4 \\
(0.03)\end{array}$ & $\begin{array}{r}7.3 \\
(0.11)\end{array}$ & $\begin{array}{r}2.5 \\
(0.05)\end{array}$ & $\begin{array}{r}6.0 \\
(0.11)\end{array}$ \\
\hline$[35,45)$ & $\begin{array}{r}5.1 \\
(0.03)\end{array}$ & $\begin{array}{r}9.9 \\
(0.04)\end{array}$ & $\begin{array}{r}3.7 \\
(0.01)\end{array}$ & $\begin{array}{r}8.6 \\
(0.02)\end{array}$ & $\begin{array}{r}1.7 \\
(0.01)\end{array}$ & $\begin{array}{r}4.5 \\
(0.02)\end{array}$ & $\begin{array}{r}1.9 \\
(0.04)\end{array}$ & $\begin{array}{r}5.7 \\
(0.14)\end{array}$ & $\begin{array}{r}2.1 \\
(0.05)\end{array}$ & $\begin{array}{r}4.9 \\
(0.09)\end{array}$ \\
\hline$[45,55]$ & $\begin{array}{r}4.9 \\
(0.04) \\
\end{array}$ & $\begin{array}{r}9.2 \\
(0.06) \\
\end{array}$ & $\begin{array}{r}3.4 \\
(0.02) \\
\end{array}$ & $\begin{array}{r}7.6 \\
(0.03) \\
\end{array}$ & $\begin{array}{r}1.4 \\
(0.01)\end{array}$ & $\begin{array}{r}3.5 \\
(0.02) \\
\end{array}$ & $\begin{array}{r}1.6 \\
(0.06) \\
\end{array}$ & $\begin{array}{r}4.7 \\
(0.18) \\
\end{array}$ & $\begin{array}{r}2.0 \\
(0.08) \\
\end{array}$ & $\begin{array}{r}4.3 \\
(0.15) \\
\end{array}$ \\
\hline Mexico & 1980 & 2010 & 1980 & 2010 & 1980 & 2010 & 1980 & 2010 & 1980 & 2010 \\
\hline$[15,25)$ & $\begin{array}{r}6.2 \\
(0.04)\end{array}$ & $\begin{array}{r}11.1 \\
(0.03)\end{array}$ & $\begin{array}{r}4.9 \\
(0.02)\end{array}$ & $\begin{array}{r}10.2 \\
(0.01)\end{array}$ & $\begin{array}{r}2.5 \\
(0.02)\end{array}$ & $\begin{array}{r}8.5 \\
(0.01)\end{array}$ & $\begin{array}{r}3.0 \\
(0.06)\end{array}$ & $\begin{array}{r}8.3 \\
(0.07)\end{array}$ & $\begin{array}{r}3.2 \\
(0.07)\end{array}$ & $\begin{array}{r}8.2 \\
(0.03)\end{array}$ \\
\hline$[25,35)$ & $\begin{array}{r}5.6 \\
(0.06)\end{array}$ & $\begin{array}{r}12.5 \\
(0.04)\end{array}$ & $\begin{array}{r}3.9 \\
(0.03)\end{array}$ & $\begin{array}{r}10.6 \\
(0.01)\end{array}$ & $\begin{array}{r}1.7 \\
(0.02)\end{array}$ & $\begin{array}{r}7.1 \\
(0.02)\end{array}$ & $\begin{array}{r}2.4 \\
(0.10)\end{array}$ & $\begin{array}{r}7.0 \\
(0.15)\end{array}$ & $\begin{array}{r}2.2 \\
(0.10)\end{array}$ & $\begin{array}{r}7.1 \\
(0.03)\end{array}$ \\
\hline$[35,45)$ & $\begin{array}{r}4.9 \\
(0.07)\end{array}$ & $\begin{array}{r}11.7 \\
(0.05)\end{array}$ & $\begin{array}{r}3.0 \\
(0.03)\end{array}$ & $\begin{array}{r}9.8 \\
(0.01)\end{array}$ & $\begin{array}{r}1.3 \\
(0.02)\end{array}$ & $\begin{array}{r}6.0 \\
(0.01)\end{array}$ & $\begin{array}{r}2.2 \\
(0.16)\end{array}$ & $\begin{array}{r}6.5 \\
(0.14)\end{array}$ & $\begin{array}{r}1.7 \\
(0.08)\end{array}$ & $\begin{array}{r}6.4 \\
(0.03)\end{array}$ \\
\hline$[45,55]$ & $\begin{array}{r}4.7 \\
(0.10)\end{array}$ & $\begin{array}{r}10.8 \\
(0.08)\end{array}$ & $\begin{array}{r}2.7 \\
(0.05)\end{array}$ & $\begin{array}{r}8.9 \\
(0.02)\end{array}$ & $\begin{array}{r}1.0 \\
(0.03)\end{array}$ & $\begin{array}{r}4.6 \\
(0.03)\end{array}$ & $\begin{array}{r}2.0 \\
(0.19)\end{array}$ & $\begin{array}{r}5.5 \\
(0.29)\end{array}$ & $\begin{array}{r}1.5 \\
(0.12)\end{array}$ & $\begin{array}{r}5.5 \\
(0.05)\end{array}$ \\
\hline
\end{tabular}

Note: Standard errors in parenthesis.

These gaps are perfectly mirrored by the proportion of women with primary education or less. For all age groups and in all three countries, the percentage of women with primary education or less 
among live-in domestic workers ranges from 65\% in Brazil (2010), to a 100\% in Mexico (1970) (Table A2).

Based on these figures, it is clear that the urban educational advantage over rural areas remains significant over the period of analysis. On the contrary, the benefit of live-in domestic workers compared to women living in rural areas is small. In addition, the educational profile of live-in and live-out domestic workers are very similar, which reinforces the idea that women change between these two forms of work over the life course.

These large and sustained educational gaps between women in large cities and urban areas and domestic workers would not surprise scholars working on racial/ethnic inequalities in LACar. Indigenous populations in Mexico and black and indigenous populations in Brazil and Colombia are overrepresented among domestic workers. According to the most recent round of censuses, while these groups of women represent less than $10 \%$ of women in large Brazilian cities and less than $4 \%$ in Colombian and Mexican large cities, their share among live-in domestic workers is above $25 \%$ in the former and $15 \%$ in the two latter countries. The lack of comparable information prevents us from computing these figures for the other censuses rounds, however, these figures are likely to be similar in previous years.

This overrepresentation means that some domestic workers suffer from an additional layer of disadvantage due to the long-lasting historical discrimination that affect their communities. Since the times of independence, ethnic and racial minorities in LACar have faced several forms of structural and institutional discrimination. From states' absolute negligence, such as in the Colombian Guajira region, to the daily life racism and discrimination in the health and educational systems, and the job market (L. S. Pinheiro et al., 2009; Woo-Mora, 2021). In addition, Black, Afro, and Indigenous populations in Colombia, Mexico and Brazil tend to reside in rural areas, 
therefore suffering the lack of access to basic services, public infrastructure, quality education, and economic opportunities typical of these areas; not to mention the disproportionate burden of violence.

To briefly restate it, the paradox is: how it is possible that, given the strong dependence between fertility and women's socioeconomic characteristics, two minority groups with divergent socioeconomic profiles, i.e., socially distal in terms of class position, display similar fertility patterns. It seems even more paradoxical that the disadvantaged minority displays sustained lower and later fertility than high-class women.

\section{Solving the paradox}

We focus on three material aspects related to live-in domestic workers' living conditions and life courses to shed light on why their fertility patterns resemble those of women in large cities, in particular those of well-off women in social and economic terms. This examination challenges the commonly accepted view that live-in domestic workers learn and adopt low fertility due to the influence of their mistress.

The first aspect is how marital status changes over the life course of live-in domestic workers vs. other women. The second includes migration status as a factor determining life course opportunities, and the third one pertains to the relationship between live-in domestic workers and their employers (power relations). More specifically, this third aspect shows that having live-in domestic workers associates with higher fertility among high-class employers. In contrast, this association is negative or non-existent when the employer is from a low-class background. In these three aspects, the subordinated position of live-in domestic women makes them less likely to have children or fewer than expected. 
Marital status: Table 4 displays age-specific proportions of women "in union" or formally married in the three geographical areas, and for live-in and live-out domestic workers. Although marriage and union formation rates have remained high (i.e., above $70 \%$ for women aged 35 or more in the first round of censuses), recent cohorts display lower levels and later marriage and union formation, with levels that range from $57 \%$ to $83 \%$ by ages 45 to 55 . Geography is a major axis of variation with women in rural areas displaying higher and earlier marriage and union formation.

Table 4. Age-specific percentage of married or 'in union' women by country and place of residence, and for domestic live-in and live-out workers

\begin{tabular}{|c|c|c|c|c|c|c|c|c|c|c|}
\hline \multirow{2}{*}{$\begin{array}{c}\begin{array}{c}\text { Country and } \\
\text { age group }\end{array} \\
\text { Brazil } \\
\end{array}$} & \multicolumn{2}{|c|}{ Large cities } & \multicolumn{2}{|c|}{ Urban are as } & \multicolumn{2}{|c|}{ Rural are as } & \multicolumn{2}{|c|}{$\begin{array}{c}\text { Live-in } \\
\text { domestic } \\
\text { workers }\end{array}$} & \multicolumn{2}{|c|}{$\begin{array}{l}\text { Live-out } \\
\text { domestic } \\
\text { workers }\end{array}$} \\
\hline & 1980 & 2010 & 1980 & 2010 & 1980 & 2010 & 1980 & 2010 & 1980 & 2010 \\
\hline$[15,25)$ & $\begin{array}{r}27 \\
(0.07)\end{array}$ & $\begin{array}{r}20 \\
(0.10)\end{array}$ & $\begin{array}{r}31 \\
(0.03)\end{array}$ & $\begin{array}{r}28 \\
(0.03)\end{array}$ & $\begin{array}{r}39 \\
(0.05)\end{array}$ & $\begin{array}{r}37 \\
(0.06)\end{array}$ & $\begin{array}{r}0 \\
(0.02)\end{array}$ & $\begin{array}{r}1 \\
(0.12)\end{array}$ & $\begin{array}{r}12 \\
(0.07)\end{array}$ & $\begin{array}{r}37 \\
(0.12)\end{array}$ \\
\hline$[25,35)$ & $\begin{array}{r}71 \\
(0.09)\end{array}$ & $\begin{array}{r}57 \\
(0.18)\end{array}$ & $\begin{array}{r}76 \\
(0.04)\end{array}$ & $\begin{array}{r}65 \\
(0.05)\end{array}$ & $\begin{array}{r}84 \\
(0.06)\end{array}$ & $\begin{array}{r}78 \\
(0.10)\end{array}$ & $\begin{array}{r}2 \\
(0.05)\end{array}$ & $\begin{array}{r}2 \\
(0.17)\end{array}$ & $\begin{array}{r}52 \\
(0.18)\end{array}$ & $\begin{array}{r}65 \\
(0.14)\end{array}$ \\
\hline$[35,45)$ & $\begin{array}{r}76 \\
(0.11)\end{array}$ & $\begin{array}{r}67 \\
(0.21)\end{array}$ & $\begin{array}{r}80 \\
(0.05)\end{array}$ & $\begin{array}{r}71 \\
(0.06)\end{array}$ & $\begin{array}{r}87 \\
(0.06)\end{array}$ & $\begin{array}{r}84 \\
(0.11)\end{array}$ & $\begin{array}{r}2 \\
(0.09)\end{array}$ & $\begin{array}{r}3 \\
(0.28)\end{array}$ & $\begin{array}{r}56 \\
(0.21)\end{array}$ & $\begin{array}{r}66 \\
(0.14)\end{array}$ \\
\hline$[45,55]$ & $\begin{array}{r}72 \\
(0.15) \\
\end{array}$ & $\begin{array}{r}63 \\
(0.29) \\
\end{array}$ & $\begin{array}{r}74 \\
(0.08) \\
\end{array}$ & $\begin{array}{r}68 \\
(0.08) \\
\end{array}$ & $\begin{array}{r}83 \\
(0.10) \\
\end{array}$ & $\begin{array}{r}83 \\
(0.15) \\
\end{array}$ & $\begin{array}{r}1 \\
(0.13)\end{array}$ & $\begin{array}{r}4 \\
(0.45) \\
\end{array}$ & $\begin{array}{r}49 \\
(0.31) \\
\end{array}$ & $\begin{array}{r}60 \\
(0.20) \\
\end{array}$ \\
\hline Colombia & 1973 & 2005 & 1973 & 2005 & 1973 & 2005 & 1973 & 2005 & 1973 & 2005 \\
\hline$[15,25)$ & $\begin{array}{r}26 \\
(0.21)\end{array}$ & $\begin{array}{r}21 \\
(0.16)\end{array}$ & $\begin{array}{r}28 \\
(0.13)\end{array}$ & $\begin{array}{r}26 \\
(0.08)\end{array}$ & $\begin{array}{r}37 \\
(0.18)\end{array}$ & $\begin{array}{r}38 \\
(0.09)\end{array}$ & $\begin{array}{r}5 \\
(0.12)\end{array}$ & $\begin{array}{r}5 \\
(0.29)\end{array}$ & $\begin{array}{r}23 \\
(0.63)\end{array}$ & $\begin{array}{r}23 \\
(0.37)\end{array}$ \\
\hline$[25,35)$ & $\begin{array}{r}70 \\
(0.30)\end{array}$ & $\begin{array}{r}56 \\
(0.36)\end{array}$ & $\begin{array}{r}70 \\
(0.21)\end{array}$ & $\begin{array}{r}62 \\
(0.19)\end{array}$ & $\begin{array}{r}78 \\
(0.25)\end{array}$ & $\begin{array}{r}74 \\
(0.19)\end{array}$ & $\begin{array}{r}14 \\
(0.41)\end{array}$ & $\begin{array}{r}11 \\
(0.55)\end{array}$ & $\begin{array}{r}49 \\
(1.02)\end{array}$ & $\begin{array}{r}44 \\
(0.88)\end{array}$ \\
\hline$[35,45)$ & $\begin{array}{r}74 \\
(0.35)\end{array}$ & $\begin{array}{r}63 \\
(0.42)\end{array}$ & $\begin{array}{r}74 \\
(0.24)\end{array}$ & $\begin{array}{r}67 \\
(0.22)\end{array}$ & $\begin{array}{r}81 \\
(0.26)\end{array}$ & $\begin{array}{r}78 \\
(0.23)\end{array}$ & $\begin{array}{r}18 \\
(0.64)\end{array}$ & $\begin{array}{r}15 \\
(1.18)\end{array}$ & $\begin{array}{r}48 \\
(1.05)\end{array}$ & $\begin{array}{r}43 \\
(0.95)\end{array}$ \\
\hline$[45,55]$ & $\begin{array}{r}66 \\
(0.54)\end{array}$ & $\begin{array}{r}57 \\
(0.59)\end{array}$ & $\begin{array}{r}66 \\
(0.34)\end{array}$ & $\begin{array}{r}62 \\
(0.32)\end{array}$ & $\begin{array}{r}73 \\
(0.38)\end{array}$ & $\begin{array}{r}75 \\
(0.34)\end{array}$ & $\begin{array}{r}16 \\
(0.91)\end{array}$ & $\begin{array}{r}12 \\
(1.40)\end{array}$ & $\begin{array}{r}43 \\
(1.53)\end{array}$ & $\begin{array}{r}42 \\
(2.12)\end{array}$ \\
\hline Mexico & 1970 & 2010 & 1970 & 2010 & 1970 & 2010 & 1970 & 2010 & 1970 & 2010 \\
\hline$[15,25)$ & $\begin{array}{r}30 \\
(0.53)\end{array}$ & $\begin{array}{r}18 \\
(0.23)\end{array}$ & $\begin{array}{r}36 \\
(0.33)\end{array}$ & $\begin{array}{r}29 \\
(0.08)\end{array}$ & $\begin{array}{r}47 \\
(0.36)\end{array}$ & $\begin{array}{r}37 \\
(0.12)\end{array}$ & $\begin{array}{r}8 \\
(0.59)\end{array}$ & $\begin{array}{r}5 \\
(0.38)\end{array}$ & $\begin{array}{r}13 \\
(0.72)\end{array}$ & $\begin{array}{r}21 \\
(0.31)\end{array}$ \\
\hline$[25,35)$ & $\begin{array}{r}75 \\
(0.70)\end{array}$ & $\begin{array}{r}53 \\
(0.49)\end{array}$ & $\begin{array}{r}81 \\
(0.39)\end{array}$ & $\begin{array}{r}69 \\
(0.14)\end{array}$ & $\begin{array}{r}86 \\
(0.43)\end{array}$ & $\begin{array}{r}78 \\
(0.19)\end{array}$ & $\begin{array}{r}23 \\
(1.54)\end{array}$ & $\begin{array}{r}14 \\
(1.15)\end{array}$ & $\begin{array}{r}41 \\
(1.84)\end{array}$ & $\begin{array}{r}51 \\
(0.53)\end{array}$ \\
\hline$[35,45)$ & $\begin{array}{r}80 \\
(0.77)\end{array}$ & $\begin{array}{r}64 \\
(0.55)\end{array}$ & $\begin{array}{r}84 \\
(0.45)\end{array}$ & $\begin{array}{r}76 \\
(0.15)\end{array}$ & $\begin{array}{r}88 \\
(0.49)\end{array}$ & $\begin{array}{r}83 \\
(0.25)\end{array}$ & $\begin{array}{r}29 \\
(2.59)\end{array}$ & $\begin{array}{r}20 \\
(1.55)\end{array}$ & $\begin{array}{r}49 \\
(1.89)\end{array}$ & $\begin{array}{r}58 \\
(0.52)\end{array}$ \\
\hline$[45,55]$ & $\begin{array}{r}71 \\
(1.23)\end{array}$ & $\begin{array}{r}62 \\
(0.79)\end{array}$ & $\begin{array}{r}78 \\
(0.69)\end{array}$ & $\begin{array}{r}73 \\
(0.22)\end{array}$ & $\begin{array}{r}82 \\
(0.71)\end{array}$ & $\begin{array}{r}81 \\
(0.29)\end{array}$ & $\begin{array}{r}25 \\
(4.10)\end{array}$ & $\begin{array}{r}10 \\
(1.49)\end{array}$ & $\begin{array}{r}46 \\
(2.74)\end{array}$ & $\begin{array}{r}52 \\
(0.66)\end{array}$ \\
\hline
\end{tabular}

Note: Standard errors in parenthesis. 
Consistent with fertility, live-in domestic workers display the lowest proportion of marriage and union formation at all ages, and in all three countries. These percentages are strikingly low in Brazil where the highest percentage of married or "in union" women only reached $4 \%$ among 45 to 55 years old in 2010 . This very low percentage only compares with the $12 \%$ and $10 \%$ of married or "in union" live-in domestic workers in Colombia 2005 and Mexico 2010, respectively, which are also lower than other women in these two countries. Indeed, these figures are lower than those observed among non-domestic worker women in the first age group (15 to 25). This means that marriage and union formation rates by late adulthood for live-in domestic workers are lower than marriage and union rates for all women at the onset of transition to adulthood: $20 \%$ in Brazil in 2010, $21 \%$ in Colombia in 2005, and $18 \%$ in Mexico in 2010.

The lower percentages of married women and women in union among the most recent census rounds compared to the old ones are partially explained by increases in divorces and separations; another feature of contemporary family change in the region. Yet, none of these declines compares in magnitude with the high marital and union dissolution among live-in domestic workers. According to Table 5, across the three geographical areas, large cities display the highest rates of separation/divorce in the 2000s and 2010s. The prevalence of divorce/separation in large cities increases with age, therefore being the highest among women in the last age group: $22 \%$ in Brazil in $2010,15 \%$ in Colombia in 2005, and $16 \%$ in Mexico in 2010. All these figures are low compared to the prevalence of divorce/separation of the same age group among live-in and live-out domestic workers. These percentages range from $21 \%$ in Colombia in 2005 to $42 \%$ among live-in domestic workers in Brazil in 2010. Indeed, live-out domestic workers display higher prevalence of separation/divorce than live-in domestic workers at all ages in Colombia and Mexico, but not in 
Brazil. Which, again underlines the specificity of live-in domestic arrangements in the southern cone nation.

Table 5. Age-specific percentage separated/divorced women by country and place of residence, and for domestic live-in and live-out workers.

\begin{tabular}{|c|c|c|c|c|c|c|c|c|c|c|}
\hline \multirow{2}{*}{$\begin{array}{l}\begin{array}{c}\text { Country and } \\
\text { age group }\end{array} \\
\text { Brazil }\end{array}$} & \multicolumn{2}{|c|}{ Large cities } & \multicolumn{2}{|c|}{ Urban are as } & \multicolumn{2}{|c|}{ Rural areas } & \multicolumn{2}{|c|}{$\begin{array}{c}\text { Live-in } \\
\text { domestic } \\
\text { workers }\end{array}$} & \multicolumn{2}{|c|}{$\begin{array}{c}\text { Live-out } \\
\text { domestic } \\
\text { workers }\end{array}$} \\
\hline & 1980 & 2010 & 1980 & 2010 & 1980 & 2010 & 1980 & 2010 & 1980 & 2010 \\
\hline$[15,25)$ & $\begin{array}{r}1 \\
(0.02)\end{array}$ & $\begin{array}{r}5 \\
(0.09)\end{array}$ & $\begin{array}{r}1 \\
(0.01)\end{array}$ & $\begin{array}{r}6 \\
(0.03)\end{array}$ & $\begin{array}{r}1 \\
(0.01)\end{array}$ & $\begin{array}{r}5 \\
(0.04)\end{array}$ & $\begin{array}{r}2 \\
(0.04)\end{array}$ & $\begin{array}{r}11 \\
(0.47)\end{array}$ & $\begin{array}{r}2 \\
(0.04)\end{array}$ & $\begin{array}{r}12 \\
(0.14)\end{array}$ \\
\hline$[25,35)$ & $\begin{array}{r}4 \\
(0.04)\end{array}$ & $\begin{array}{r}12 \\
(0.13)\end{array}$ & $\begin{array}{r}3 \\
(0.02)\end{array}$ & $\begin{array}{r}13 \\
(0.04)\end{array}$ & $\begin{array}{r}2 \\
(0.02)\end{array}$ & $\begin{array}{r}8 \\
(0.06)\end{array}$ & $\begin{array}{r}8 \\
(0.14)\end{array}$ & $\begin{array}{r}27 \\
(0.74)\end{array}$ & $\begin{array}{r}10 \\
(0.11)\end{array}$ & $\begin{array}{r}20 \\
(0.13)\end{array}$ \\
\hline$[35,45)$ & $\begin{array}{r}7 \\
(0.06)\end{array}$ & $\begin{array}{r}18 \\
(0.16)\end{array}$ & $\begin{array}{r}5 \\
(0.02)\end{array}$ & $\begin{array}{r}17 \\
(0.04)\end{array}$ & $\begin{array}{r}2 \\
(0.02)\end{array}$ & $\begin{array}{r}8 \\
(0.06)\end{array}$ & $\begin{array}{r}13 \\
(0.28)\end{array}$ & $\begin{array}{r}39 \\
(0.98)\end{array}$ & $\begin{array}{r}15 \\
(0.15)\end{array}$ & $\begin{array}{r}24 \\
(0.13)\end{array}$ \\
\hline$[45,55]$ & $\begin{array}{r}8 \\
(0.09) \\
\end{array}$ & $\begin{array}{r}22 \\
(0.24) \\
\end{array}$ & $\begin{array}{r}6 \\
(0.04) \\
\end{array}$ & $\begin{array}{r}19 \\
(0.07) \\
\end{array}$ & $\begin{array}{r}3 \\
(0.04) \\
\end{array}$ & $\begin{array}{r}9 \\
(0.09) \\
\end{array}$ & $\begin{array}{r}14 \\
(0.45) \\
\end{array}$ & $\begin{array}{r}42 \\
(1.40) \\
\end{array}$ & $\begin{array}{r}16 \\
(0.23) \\
\end{array}$ & $\begin{array}{r}28 \\
(0.19) \\
\end{array}$ \\
\hline Colombia & 1973 & 2005 & 1973 & 2005 & 1973 & 2005 & 1973 & 2005 & 1973 & 2005 \\
\hline & $\begin{array}{r}1 \\
(0.04)\end{array}$ & $\begin{array}{r}1 \\
(0.09)\end{array}$ & $\begin{array}{r}1 \\
(0.03)\end{array}$ & $\begin{array}{r}2 \\
(0.05)\end{array}$ & $\begin{array}{r}1 \\
(0.03)\end{array}$ & $\begin{array}{r}2 \\
(0.06)\end{array}$ & $\begin{array}{r}1 \\
(0.08)\end{array}$ & $\begin{array}{r}2 \\
(0.36)\end{array}$ & $\begin{array}{r}3 \\
(0.31)\end{array}$ & $\begin{array}{r}6 \\
(0.80)\end{array}$ \\
\hline$[25,35)$ & $\begin{array}{r}3 \\
(0.11)\end{array}$ & $\begin{array}{r}6 \\
(0.20)\end{array}$ & $\begin{array}{r}3 \\
(0.07)\end{array}$ & $\begin{array}{r}7 \\
(0.11)\end{array}$ & $\begin{array}{r}1 \\
(0.06)\end{array}$ & $\begin{array}{r}4 \\
(0.09)\end{array}$ & $\begin{array}{r}6 \\
(0.35)\end{array}$ & $\begin{array}{r}9 \\
(0.79)\end{array}$ & $\begin{array}{r}9 \\
(0.63)\end{array}$ & $\begin{array}{r}13 \\
(0.96)\end{array}$ \\
\hline$[35,45)$ & $\begin{array}{r}5 \\
(0.16)\end{array}$ & $\begin{array}{r}11 \\
(0.27)\end{array}$ & $\begin{array}{r}5 \\
(0.10)\end{array}$ & $\begin{array}{r}11 \\
(0.14)\end{array}$ & $\begin{array}{r}2 \\
(0.07)\end{array}$ & $\begin{array}{r}5 \\
(0.11)\end{array}$ & $\begin{array}{r}7 \\
(0.52)\end{array}$ & $\begin{array}{r}17 \\
(1.30)\end{array}$ & $\begin{array}{r}12 \\
(0.74)\end{array}$ & $\begin{array}{r}20 \\
(1.24)\end{array}$ \\
\hline$[45,55]$ & $\begin{array}{r}5 \\
(0.25) \\
\end{array}$ & $\begin{array}{r}15 \\
(0.42) \\
\end{array}$ & $\begin{array}{r}6 \\
(0.16) \\
\end{array}$ & $\begin{array}{r}13 \\
(0.22) \\
\end{array}$ & $\begin{array}{r}2 \\
(0.11) \\
\end{array}$ & $\begin{array}{r}6 \\
(0.18) \\
\end{array}$ & $\begin{array}{r}7 \\
(0.77) \\
\end{array}$ & $\begin{array}{r}21 \\
(2.13) \\
\end{array}$ & $\begin{array}{r}11 \\
(1.04) \\
\end{array}$ & $\begin{array}{r}22 \\
(2.07) \\
\end{array}$ \\
\hline Mexico & 1970 & 2010 & 1970 & 2010 & 1970 & 2010 & 1970 & 2010 & 1970 & 2010 \\
\hline & $\begin{array}{r}1 \\
(0.14)\end{array}$ & $\begin{array}{r}2 \\
(0.14)\end{array}$ & $\begin{array}{r}1 \\
(0.08)\end{array}$ & $\begin{array}{r}2 \\
(0.04)\end{array}$ & $\begin{array}{r}1 \\
(0.09)\end{array}$ & $\begin{array}{r}2 \\
(0.04)\end{array}$ & $\begin{array}{r}5 \\
(0.56)\end{array}$ & $\begin{array}{r}2 \\
(0.35)\end{array}$ & $\begin{array}{r}3 \\
(0.50)\end{array}$ & $\begin{array}{r}7 \\
(0.32)\end{array}$ \\
\hline$[25,35)$ & $\begin{array}{r}4 \\
(0.30)\end{array}$ & $\begin{array}{r}7 \\
(0.26)\end{array}$ & $\begin{array}{r}3 \\
(0.14)\end{array}$ & $\begin{array}{r}7 \\
(0.08)\end{array}$ & $\begin{array}{r}2 \\
(0.13)\end{array}$ & $\begin{array}{r}5 \\
(0.07)\end{array}$ & $\begin{array}{r}22 \\
(1.85)\end{array}$ & $\begin{array}{r}10 \\
(1.16)\end{array}$ & $\begin{array}{r}18 \\
(1.60)\end{array}$ & $\begin{array}{r}18 \\
(0.40)\end{array}$ \\
\hline$[35,45)$ & $\begin{array}{r}6 \\
(0.41)\end{array}$ & $\begin{array}{r}13 \\
(0.36)\end{array}$ & $\begin{array}{r}4 \\
(0.19)\end{array}$ & $\begin{array}{r}11 \\
(0.10)\end{array}$ & $\begin{array}{r}2 \\
(0.16)\end{array}$ & $\begin{array}{r}6 \\
(0.09)\end{array}$ & $\begin{array}{r}20 \\
(2.59)\end{array}$ & $\begin{array}{r}14 \\
(1.56)\end{array}$ & $\begin{array}{r}21 \\
(1.61)\end{array}$ & $\begin{array}{r}22 \\
(0.41)\end{array}$ \\
\hline$[45,55]$ & $\begin{array}{r}6 \\
(0.62)\end{array}$ & $\begin{array}{r}16 \\
(0.58)\end{array}$ & $\begin{array}{r}5 \\
(0.31) \\
\end{array}$ & $\begin{array}{r}13 \\
(0.15)\end{array}$ & $\begin{array}{r}3 \\
(0.24)\end{array}$ & $\begin{array}{r}6 \\
(0.13)\end{array}$ & $\begin{array}{r}23 \\
(4.10)\end{array}$ & $\begin{array}{r}21 \\
(3.08)\end{array}$ & $\begin{array}{r}14 \\
(2.04)\end{array}$ & $\begin{array}{r}25 \\
(0.59)\end{array}$ \\
\hline
\end{tabular}

Note: Standard errors in parenthesis.

Another aspect that deserves attention is the timing of these events. By age 35, in the most recent census rounds, at least $9 \%$ of live-in domestic workers women are separated or divorced. That proportion rises to 39\%, 17\%, and $14 \%$ by age 45 in Brazil, Colombia, and Mexico, respectively. Together with the results on marriage, these separation/divorce patterns suggest that domestic 
workers' life courses involve either no transition to union formation or union formation that rapidly transforms into separations for a sizable fraction of them.

Domestic migration: A potential factor on the low number of children among domestic workers is the high prevalence of domestic migration, particularly at younger ages. This is not to say that, in general, domestic migration associates with lower fertility, but to emphasize that for live-in and live-out domestic workers (i.e., low educated women in unstable unions/marriages, who are very young when they enter the labor force and cannot afford to live by themselves), migration does contribute to lower fertility.

According to Table 6, in the 1990s, half of the live-in domestic workers aged 15 to 25 in Brazil and Colombia and one-third in Mexico were recent immigrants (i.e., they lived in a different administrative area five years prior to the census). The proportions of recent immigrants are above $10 \%$ in all age groups and all years among live-in domestic workers (except in Mexico 1990 for women aged 45 to 55), which is rarely seen among other women. The prevalence of recent migration for other women is high at ages 15 to 25 , but never as high as for live-in domestic workers. In addition, the prevalence of recent immigration among non-domestic workers decreases with age to levels below $10 \%$ by late adulthood.

The decreasing prevalence of recent immigration across the censuses, as depicted in Table 6, stems from the consolidation of urbanization processes. With the exception of Mexico (where recent immigration prevalence increased or remained stable between 1990 and 2010), recent immigration prevalence decreased for all age groups and in all geographical areas between the oldest and most recent census. In the first age group, i.e., among women aged 15 to 25 , these changes are very consistent between domestic workers and all other women, despite the higher migration rates of the former. Instead, the changes in the prevalence of migration over time for older ages are the 
opposite if one compares live-in domestic workers and other women. These reversed trends further highlight the uniqueness of the living condition of live-in domestic workers. For example, for women age 35 to 45, the percentage of recent immigrant women among live-in domestic workers across the two censuses are: 17\%-16\% in Brazil, 24\%-26\% in Colombia, and 13\%-22\% in Mexico; these are all high figures, signaling the higher and extended mobility of live-in domestic workers. There is no other group of women with comparable levels of recent immigration at this age or even at younger ages.

Table 6. Age-specific percentage of recent domestic immigration by country and place of residence, and for domestic live-in and live-out workers

\begin{tabular}{|c|c|c|c|c|c|c|c|c|c|c|}
\hline \multirow{2}{*}{$\begin{array}{c}\begin{array}{c}\text { Country and } \\
\text { age group }\end{array} \\
\text { Brazil }\end{array}$} & \multicolumn{2}{|c|}{ Large cities } & \multicolumn{2}{|c|}{ Urban are as } & \multicolumn{2}{|c|}{ Rural are as } & \multicolumn{2}{|c|}{$\begin{array}{c}\text { Live-in } \\
\text { domestic } \\
\text { workers }\end{array}$} & \multicolumn{2}{|c|}{$\begin{array}{r}\text { Live-out } \\
\text { domestic } \\
\text { workers }\end{array}$} \\
\hline & 1990 & 2010 & 1990 & 2010 & 1990 & 2010 & 1990 & 2010 & 1990 & 2010 \\
\hline$[15,25)$ & $\begin{array}{r}9 \\
(0.09)\end{array}$ & $\begin{array}{r}6 \\
(0.10)\end{array}$ & $\begin{array}{r}15 \\
(0.04)\end{array}$ & $\begin{array}{r}11 \\
(0.03)\end{array}$ & $\begin{array}{r}11 \\
(0.06)\end{array}$ & $\begin{array}{r}8 \\
(0.05)\end{array}$ & $\begin{array}{r}51 \\
(0.26)\end{array}$ & $\begin{array}{r}42 \\
(0.73)\end{array}$ & $\begin{array}{r}17 \\
(0.13)\end{array}$ & $\begin{array}{r}13 \\
(0.15)\end{array}$ \\
\hline$[25,35)$ & $\begin{array}{r}6 \\
(0.07)\end{array}$ & $\begin{array}{r}6 \\
(0.09)\end{array}$ & $\begin{array}{r}14 \\
(0.04)\end{array}$ & $\begin{array}{r}11 \\
(0.03)\end{array}$ & $\begin{array}{r}12 \\
(0.07)\end{array}$ & $\begin{array}{r}9 \\
(0.06)\end{array}$ & $\begin{array}{r}31 \\
(0.41)\end{array}$ & $\begin{array}{r}27 \\
(0.74)\end{array}$ & $\begin{array}{r}15 \\
(0.14)\end{array}$ & $\begin{array}{r}9 \\
(0.09)\end{array}$ \\
\hline$[35,45)$ & $\begin{array}{r}3 \\
(0.05)\end{array}$ & $\begin{array}{r}3 \\
(0.07)\end{array}$ & $\begin{array}{r}10 \\
(0.04)\end{array}$ & $\begin{array}{r}7 \\
(0.03)\end{array}$ & $\begin{array}{r}8 \\
(0.07)\end{array}$ & $\begin{array}{r}7 \\
(0.05)\end{array}$ & $\begin{array}{r}17 \\
(0.53)\end{array}$ & $\begin{array}{r}16 \\
(0.72)\end{array}$ & $\begin{array}{r}10 \\
(0.14)\end{array}$ & $\begin{array}{r}6 \\
(0.07)\end{array}$ \\
\hline$[45,55]$ & $\begin{array}{r}2 \\
(0.07)\end{array}$ & $\begin{array}{r}2 \\
(0.08)\end{array}$ & $\begin{array}{r}7 \\
(0.06)\end{array}$ & $\begin{array}{r}5 \\
(0.03)\end{array}$ & $\begin{array}{r}7 \\
(0.09)\end{array}$ & $\begin{array}{r}5 \\
(0.07)\end{array}$ & $\begin{array}{r}13 \\
(0.78)\end{array}$ & $\begin{array}{r}12 \\
(0.90)\end{array}$ & $\begin{array}{r}8 \\
(0.21)\end{array}$ & $\begin{array}{r}4 \\
(0.08) \\
\end{array}$ \\
\hline Colombia & 1993 & 2005 & 1993 & 2005 & 1993 & 2005 & 1993 & 2005 & 1993 & 2005 \\
\hline$[15,25)$ & $\begin{array}{r}14 \\
(0.14)\end{array}$ & $\begin{array}{r}11 \\
(0.25)\end{array}$ & $\begin{array}{r}15 \\
(0.09)\end{array}$ & $\begin{array}{r}11 \\
(0.13)\end{array}$ & $\begin{array}{r}13 \\
(0.13)\end{array}$ & $\begin{array}{r}7 \\
(0.10)\end{array}$ & $\begin{array}{r}51 \\
(0.37)\end{array}$ & $\begin{array}{r}45 \\
(1.26)\end{array}$ & $\begin{array}{r}17 \\
(0.42)\end{array}$ & $\begin{array}{r}13 \\
(1.45)\end{array}$ \\
\hline$[25,35)$ & $\begin{array}{r}11 \\
(0.14)\end{array}$ & $\begin{array}{r}7 \\
(0.21)\end{array}$ & $\begin{array}{r}16 \\
(0.11)\end{array}$ & $\begin{array}{r}10 \\
(0.13)\end{array}$ & $\begin{array}{r}15 \\
(0.17)\end{array}$ & $\begin{array}{r}9 \\
(0.12)\end{array}$ & $\begin{array}{r}33 \\
(0.65)\end{array}$ & $\begin{array}{r}31 \\
(1.48)\end{array}$ & $\begin{array}{r}16 \\
(0.47)\end{array}$ & $\begin{array}{r}10 \\
(0.94)\end{array}$ \\
\hline$[35,45)$ & $\begin{array}{r}8 \\
(0.16)\end{array}$ & $\begin{array}{r}4 \\
(0.17)\end{array}$ & $\begin{array}{r}11 \\
(0.12)\end{array}$ & $\begin{array}{r}7 \\
(0.12)\end{array}$ & $\begin{array}{r}10 \\
(0.17)\end{array}$ & $\begin{array}{r}6 \\
(0.11)\end{array}$ & $\begin{array}{r}24 \\
(0.86)\end{array}$ & $\begin{array}{r}26 \\
(1.61)\end{array}$ & $\begin{array}{r}12 \\
(0.47)\end{array}$ & $\begin{array}{r}6 \\
(0.77)\end{array}$ \\
\hline$[45,55]$ & $\begin{array}{r}8 \\
(0.23)\end{array}$ & $\begin{array}{r}3 \\
(0.21)\end{array}$ & $\begin{array}{r}9 \\
(0.16)\end{array}$ & $\begin{array}{r}6 \\
(0.16)\end{array}$ & $\begin{array}{r}8 \\
(0.20)\end{array}$ & $\begin{array}{r}5 \\
(0.13)\end{array}$ & $\begin{array}{r}19 \\
(1.12)\end{array}$ & $\begin{array}{r}22 \\
(2.31)\end{array}$ & $\begin{array}{r}10 \\
(0.61)\end{array}$ & $\begin{array}{r}5 \\
(1.00)\end{array}$ \\
\hline Mexico & 1990 & 2010 & 1990 & 2010 & 1990 & 2010 & 1990 & 2010 & 1990 & 2010 \\
\hline$[15,25)$ & $\begin{array}{r}5 \\
(0.08)\end{array}$ & $\begin{array}{r}10 \\
(0.33)\end{array}$ & $\begin{array}{r}7 \\
(0.03)\end{array}$ & $\begin{array}{r}9 \\
(0.08)\end{array}$ & $\begin{array}{r}3 \\
(0.03)\end{array}$ & $\begin{array}{r}5 \\
(0.08)\end{array}$ & $\begin{array}{r}35 \\
(0.38)\end{array}$ & $\begin{array}{r}56 \\
(1.47)\end{array}$ & $\begin{array}{r}7 \\
(0.19)\end{array}$ & $\begin{array}{r}9 \\
(0.43)\end{array}$ \\
\hline$[25,35)$ & $\begin{array}{r}4 \\
(0.08)\end{array}$ & $\begin{array}{r}13 \\
(0.35)\end{array}$ & $\begin{array}{r}8 \\
(0.04)\end{array}$ & $\begin{array}{r}11 \\
(0.09)\end{array}$ & $\begin{array}{r}3 \\
(0.05)\end{array}$ & $\begin{array}{r}6 \\
(0.08)\end{array}$ & $\begin{array}{r}18 \\
(0.59)\end{array}$ & $\begin{array}{r}27 \\
(1.77)\end{array}$ & $\begin{array}{r}7 \\
(0.28)\end{array}$ & $\begin{array}{r}8 \\
(0.30)\end{array}$ \\
\hline$[35,45)$ & $\begin{array}{r}2 \\
(0.07)\end{array}$ & $\begin{array}{r}9 \\
(0.28)\end{array}$ & $\begin{array}{r}6 \\
(0.04)\end{array}$ & $\begin{array}{r}7 \\
(0.08)\end{array}$ & $\begin{array}{r}2 \\
(0.04)\end{array}$ & $\begin{array}{r}4 \\
(0.09)\end{array}$ & $\begin{array}{r}13 \\
(0.71)\end{array}$ & $\begin{array}{r}22 \\
(2.16)\end{array}$ & $\begin{array}{r}5 \\
(0.24)\end{array}$ & $\begin{array}{r}6 \\
(0.22)\end{array}$ \\
\hline$[45,55]$ & $\begin{array}{r}2 \\
(0.10)\end{array}$ & $\begin{array}{r}6 \\
(0.43)\end{array}$ & $\begin{array}{r}4 \\
(0.06)\end{array}$ & $\begin{array}{r}5 \\
(0.13)\end{array}$ & $\begin{array}{r}1 \\
(0.05)\end{array}$ & $\begin{array}{r}2 \\
(0.08)\end{array}$ & $\begin{array}{r}9 \\
(0.89)\end{array}$ & $\begin{array}{r}25 \\
(3.56)\end{array}$ & $\begin{array}{r}5 \\
(0.34)\end{array}$ & $\begin{array}{r}5 \\
(0.34)\end{array}$ \\
\hline
\end{tabular}

Note: Standard errors in parenthesis. 
Class status and enabling childbearing: Figure 2 displays the difference in the cumulative fertility rate between women living in households with at least one domestic worker (mistress) vs. women living in households without domestic workers. The figure includes results for three ten-year age groups that correspond to adulthood fertility (25 to 35 ), late-adulthood fertility (35 to 45 ), and complete fertility (45 to 55). The figure also separates women according to their educational attainment into four groups: less than primary (LessP), primary completed (PrimC), secondary completed (SecoC), and tertiary completed (TertC). Filled markers indicate statistically significant differences, and the size of the marker is proportional to the mean cumulative fertility of women without domestic workers at home (i.e., the reference category).

Figure 2 summarizes two critical aspects. First, the dual dynamics of the fertility transition in LACar: substantial fertility decline among lower-class women (without secondary education) and sustained relatively low fertility among high-class (secondary or tertiary education completed). Second, the divergent relationship between live-in domestic work arrangements and fertility across the social class spectrum, and between large cities and urban areas. Because the first aspect (unequal fertility decline) has been the subject of several other works, we focus on the latter: the association between domestic work and fertility by social class.

According to this figure, for women with secondary and tertiary education (i.e., high class/privileged women), there is a positive association between having a domestic worker at home and fertility for the three age groups. This means that live-in domestic workers contributed to the higher fertility of their high-class employers. There are several important features to this overarching association. First, this association is very consistent for all three age groups in large Brazilian cities and less consistent in Colombia and Mexico (Panel A). Second, given the low 
fertility of these women (especially between ages 25 to 35), the magnitude of these differences in the oldest censuses are very considerable.

Figure 2. Difference in cumulative fertility between women living in households with and without live-in domestic workers by age groups and educational attainment.

Panel A: Large cities
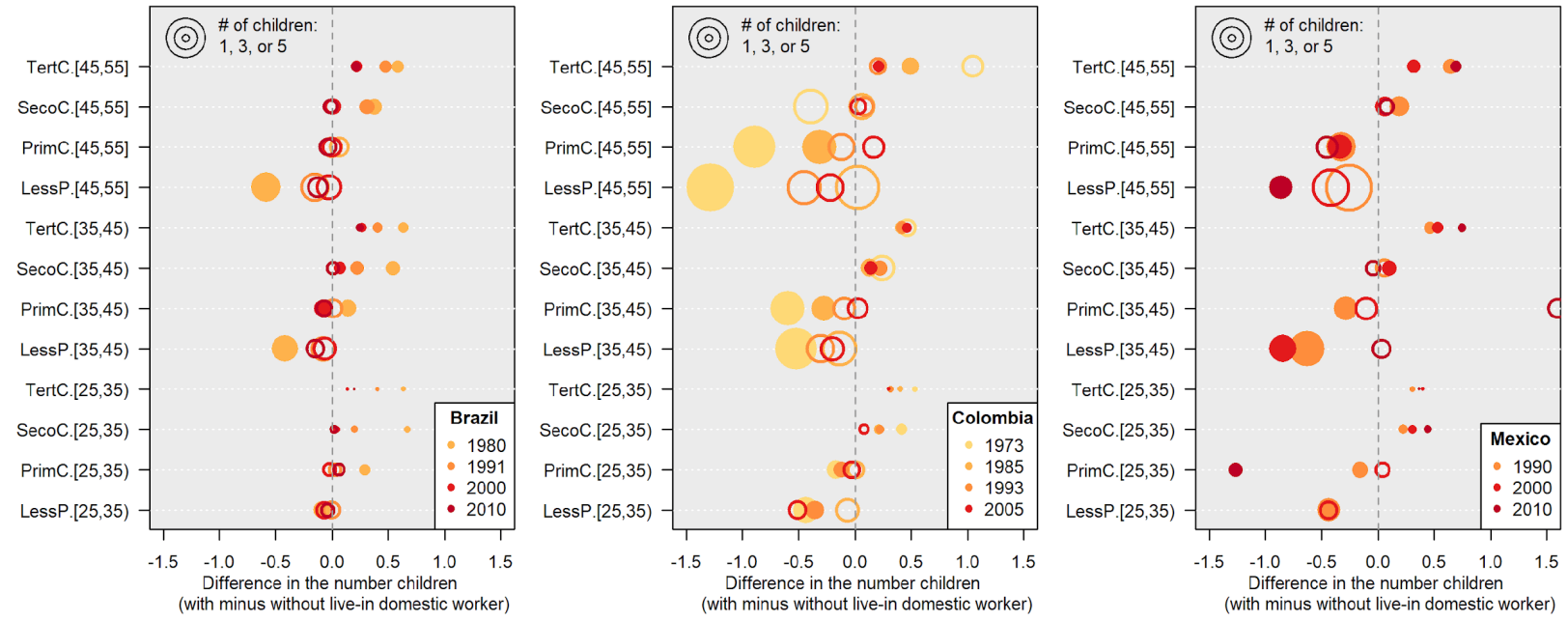

Panel B: Urban areas
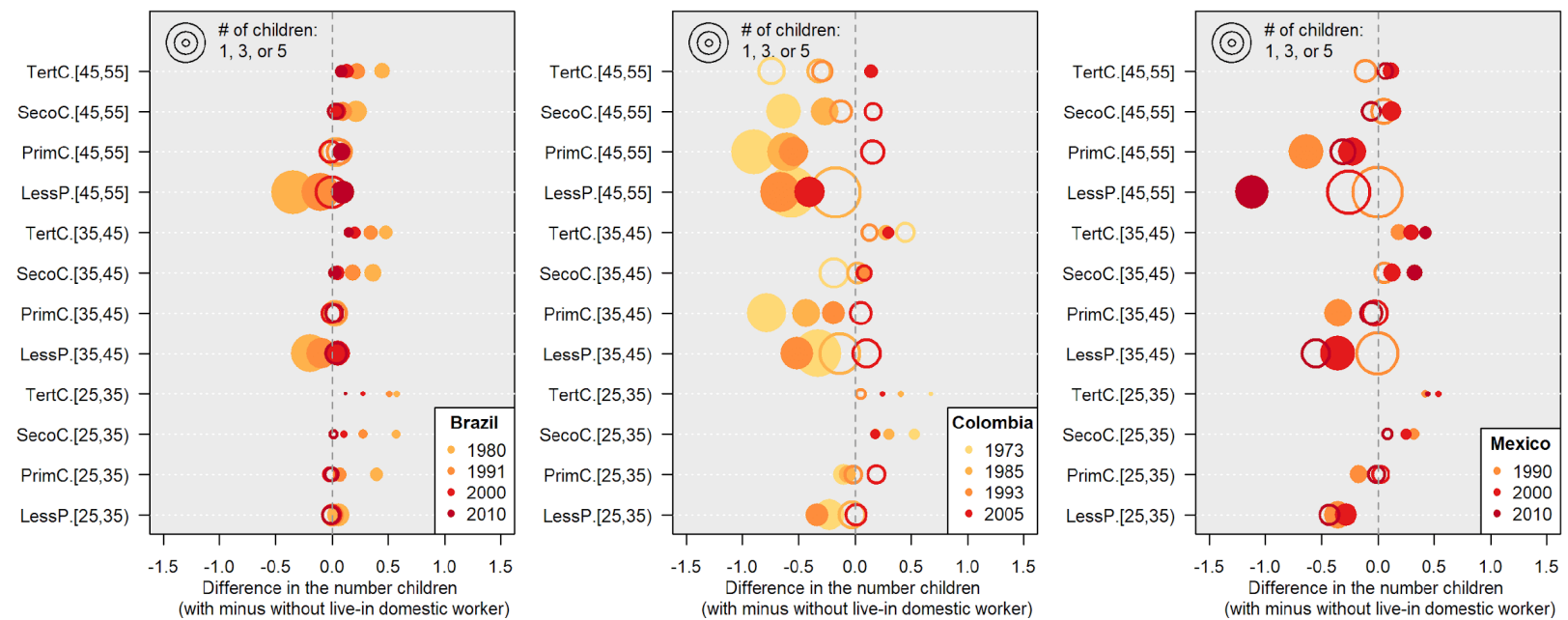

Note: Filled circles represents statistically significant differences (alpha $=0.95$ ). The size of the marker is proportional to the average number of children of women living in households without live-in domestic workers (i.e., the reference categories).

For example, in Brazil in 1980, for women with tertiary education, the difference in the fertility rate between those with domestic workers and those without is 0.6 children, which represents 
$100 \%, 48 \%$, and $37 \%$ of the mean fertility of women without domestic workers at ages 25 to 35 , 35 to 45 , and 45 to 55 , respectively. These figures are comparable in size and direction for Colombia and Mexico, although some are not statistically significant. Third, across censuses, the magnitude of the differences decreases in Brazil and Colombia, and increases in Mexico.

In contrast to these results, the association between having a live-in domestic worker and fertility for women with primary education or less is null (Brazil) or negative (Colombia and Mexico, particularly for the oldest censuses. For example, it is only for the 1980 Brazilian census, that this negative association displays significant and relatively large magnitudes in large cities. The same is true for 1973 Colombian and 1990 Mexican censuses.

The significance of these relationships for aggregated fertility and for class differences in fertility cannot be understood without acknowledging the unequal distribution of live-in domestic workers by women's educational attainment and how these figures have changed over time for some groups while remaining stable for others. As shown in Table 7, live-in domestic work is more prevalent among highly educated women. Among these groups, the proportion of women living in households with domestic workers declined from $23 \%$ in Brazil, $59 \%$ in Colombia, and $21 \%$ in Mexico in the 1970 s and 1980 s, to less than $10 \%$ in the last census round.

In contrast, the proportion of low educated women with a live-in domestic worker is small, and it has not changed over time, signaling the different nature of these arrangements compared to those at the other end of the class spectrum. Together, these results suggest that live-in domestic workers play a more significant role in the fertility of highly educated women than that of low educated. 
Table 7. Percentage of mistress women (i.e., at least one live-in domestic worker) by country and women's educational attainment.

\begin{tabular}{|c|c|c|c|c|c|}
\hline \multirow[b]{2}{*}{ Country } & \multirow[b]{2}{*}{$\begin{array}{c}\text { Census } \\
\text { year }\end{array}$} & \multicolumn{4}{|c|}{ Educational attainment } \\
\hline & & $\begin{array}{c}\text { Less than } \\
\text { primary }\end{array}$ & $\begin{array}{c}\text { Primary } \\
\text { completed }\end{array}$ & $\begin{array}{l}\text { Secondary } \\
\text { completed }\end{array}$ & $\begin{array}{c}\text { Te rtiary } \\
\text { complete d }\end{array}$ \\
\hline \multirow[t]{8}{*}{ Brazil } & 1980 & 3 & 7 & 14 & 23 \\
\hline & & $(0.01)$ & $(0.04)$ & $(0.06)$ & $(0.11)$ \\
\hline & 1991 & 4 & 5 & 8 & 14 \\
\hline & & $(0.02)$ & $(0.04)$ & $(0.05)$ & $(0.09)$ \\
\hline & 2000 & 4 & 5 & 6 & 8 \\
\hline & & $(0.02)$ & $(0.02)$ & $(0.03)$ & $(0.06)$ \\
\hline & 2010 & 4 & 4 & 4 & 5 \\
\hline & & $(0.02)$ & $(0.02)$ & $(0.02)$ & $(0.04)$ \\
\hline \multirow[t]{8}{*}{ Colombia } & 1973 & 7 & 17 & 46 & 59 \\
\hline & & $(0.06)$ & $(0.14)$ & $(0.50)$ & (1.09) \\
\hline & 1985 & 5 & 8 & 18 & 31 \\
\hline & & $(0.05)$ & $(0.07)$ & $(0.17)$ & $(0.35)$ \\
\hline & 1993 & 1 & 3 & 9 & 15 \\
\hline & & $(0.03)$ & $(0.03)$ & $(0.08)$ & $(0.43)$ \\
\hline & 2005 & 2 & 2 & 4 & 9 \\
\hline & & $(0.06)$ & $(0.07)$ & $(0.09)$ & $(0.19)$ \\
\hline \multirow[t]{8}{*}{ Mexico } & 1970 & 1 & 7 & 16 & 21 \\
\hline & & $(0.05)$ & $(0.23)$ & $(1.32)$ & (1.92) \\
\hline & 1990 & 1 & 2 & 5 & 8 \\
\hline & & $(0.01)$ & $(0.02)$ & $(0.06)$ & $(0.11)$ \\
\hline & 2000 & 1 & 1 & 3 & 6 \\
\hline & & $(0.02)$ & $(0.02)$ & $(0.04)$ & $(0.07)$ \\
\hline & 2010 & 0 & 0 & 1 & 2 \\
\hline & & $(0.01)$ & $(0.01)$ & $(0.02)$ & $(0.06)$ \\
\hline
\end{tabular}

Note: Standard errors in parenthesis.

\section{Conclusion}

Previous research in LACar portrays low fertility and fertility decline as the individual fulfillment of decreasing fertility desires across generations triggered by raising educational attainment, access to effective contraception, and a modern-like mode of living. Inspired by the "ready, willing, and able" framework (Coale, 1977), correlational studies of individuals' (typically women) socioeconomic characteristics and fertility support this narrative. The lack of attention to structural factors such as lifelong socioeconomic exclusion/discrimination and power relations 
limit the scope of these explanatory frameworks, particularly for understanding demographic patterns among socioeconomic minorities.

According to our results, the fertility patterns of live-in domestic workers in the three largest LACar countries during the second half 20th-century challenge this overarching interpretation of low fertility and fertility decline. The confluence of disadvantaged circumstances over live-in domestic workers' life courses is an important factor in their low and delayed fertility. Contrary to the experience of the majority, live-in domestic workers display a combination of living conditions that is unique in terms of disadvantages and subordination. They join the labor force very early entering an occupation that has historically lacked regulations and recognition, it is often not well paid, and it exposes women to abuse.

More generally, this group of women did not benefit from the processes of educational expansion and urbanization in the countries we study. On the contrary, urbanization and the unequal nature of educational development seem to bring detrimental consequences for these women. They put their lives aside when they work in live-in arrangements. In this context, the interpretation of their fertility patterns resulting from a learning process from the house mistress is doubtful. At the very least, an alternative hypothesis that explains their low fertility based on these material conditions is plausible. The disconnection from the family and social networks implied by live-in arrangements, the low occupational status of domestic work, the lack of family stability, and the absence of financial/economic security intersect in the life course of live-in domestic workers since early adulthood. Any demographic outcome for this population should be understood within the context of these intersecting disadvantages.

This alternative explanation also highlights the importance of power relations among women for understanding fertility differentials and the fact that the value of reproduction is stratified (Colen, 
1995). Not only are there differences in the average number of children among women from different socioeconomic backgrounds, but also differences in the value and care societies ascribed to these children, particularly to children of disadvantaged minorities. Therefore, the relevance of our results goes beyond these three concrete countries and the historical period we examine for two interrelated reasons. First, the demand for domestic work and care, and its unequal distribution have not disappeared. On the contrary, it has remained on women's shoulders, and it is becoming a transnational phenomenon where the burdens of domestic and care work are resting more and more on immigrant women from global south countries (Herrera, 2013; Sassen-Koob, 1984). Second, increasing socioeconomic inequalities warrant the perpetuation of minorities, i.e., groups of individuals suffering from social exclusion and discrimination. This means that studies of fertility differentials, and family patterns more generally, should put more effort into developing theoretical frameworks that account the social mechanisms underpinning the gaps in opportunities for families' socioeconomic well-being (and disadvantage) according to their immigrant background, racial/ethnic belonging, sexual orientation and identity, disability and socioeconomic background.

Finally, our work shows that comparing key demographic measures across groups helps to critically develop alternative hypotheses about demographic differentials and patterns when groups are defined in terms of social positions and power relations. This is an advantage of groupbased research compared to variable-based research (i.e., regression analysis) because the focus of the latter approach is on the relationships among variables, and not on the (power) relationships that define social groups. In this sense, our research can inspire further transformative investigations of families in other contexts. 


\section{References}

Adserà, A., \& Menendez, A. (2011). Fertility changes in Latin America in periods of economic uncertainty. Population Studies, 65(1), 37-56. https://doi.org/10.1080/00324728.2010.530291

Alegre, P. (2003). Estructura agraria y violencia rural en América Latina. 29.

Bethell, L. (1998). Latin America: Economy and Society Since 1930. In The Cambridge History of Latin America (1st ed.). Oxford University Press. https://doi.org/10.1017/CBO9781107415324.004

Blofield, M., \& Jokela, M. (2018). Paid domestic work and the struggles of care workers in Latin America. Current Sociology, 66(4), 531-546. https://doi.org/10.1177/0011392118765259

Brites, J. (2007). Afeto e desigualdade: Gênero, geração e classe entre empregadas domésticas e seus empregadores. Cadernos Pagu, 29, 91-109. https://doi.org/10.1590/S010483332007000200005

Castro Martin, T., \& Juarez, F. (1995). The Impact of Women's Education on Fertility In Latin America: Searching for Explanations. International Family Planning Perspectives, 21(2), 52. https://doi.org/10.2307/2133523

Chanel, E., \& Garcia Castro, M. (1989). Muchachas No More: Household Workers in Latin America and the Caribbean (1st ed.). Temple University Press.

Chant, S. (2013). Gender, Generation and Poverty. In Gender, Generation and Poverty. https://doi.org/10.4337/9781847206886

Choo, H. Y., \& Ferree, M. M. (2010). Practicing Intersectionality in Sociological Research: A Critical Analysis of Inclusions, Interactions, and Institutions in the Study of Inequalities. Sociological Theory, 28(2), 129-149. https//doi.org/10.1111/j.1467-9558.2010.01370.x

Coale, A. (1977). The Development of New Models of Nuptiality and Fertility. Population (French Edition), 32, 131. https://doi.org/10.2307/1531806

Colen, S. (1995). Like a Mother to Them': Stratified Reproduction and West Indian Childcare Workers and Employers in New York. In Conceiving the New World Order: The Global Politics of Reproduction (1st ed., p. 78). University of California Press.

De Vos, S. (1995). Household Composition in Latin America (1st ed.). Plenum Press.

Donato, K. M., Hiskey, J., Durand, J., \& Massey, D. S. (2010). Migration in the Americas: Mexico and Latin America in Comparative Context. The Annals of the American Academy of Political and Social Science, 630(1), 6-17. https://doi.org/10.1177/0002716210368101

Federici, S. (2000). Salario contra el trabajo doméstico. Debate Feminista, 22. https://doi.org/10.22201/cieg.2594066xe.2000.22.572

García, B., \& de Oliveira, O. (2011). Family Changes and Public Policies in Latin America. Annual Review of Sociology, 37(1), 593-611. https//doi.org/10.1146/annurev-soc081309-150205 
Guzmán, J., Rodríguez, J., Martínez, J., Contreras, J., \& González, D. (2006). The Demography of Latin America and the Caribbean since 1950. Population English Edition, 61(5-6), 519-576. https://doi.org/10.3917/pope.605.0519

Herrera, G. (2013). Gender and International Migration: Contributions and Cross-Fertilizations. Annual Review of Sociology, 39(1), 471-489. https//doi.org/10.1146/annurev-soc071811-145446

Hill Collins, P., \& Bilge, S. (2016). Intersectionality. Polity Press.

Ibáñez, A. M. (2009). Forced displacement in Colombia: Magnitude and causes. Economics of Peace and Security Journal, 4(1), 48-54.

ILO. (2013). Domestic workers across the world: Global and regional statistics and the extent of legal protection (p. 146). International Labour Organization.

Jelin, E. (1977). Migration and Labor Force Participation of Latin American Women: The Domestic Servants in the Cities. Signs, 3(1), 129-141. https//doi.org/10.1086/493446

Levinson, D., \& Langer, A. (2010). Counting Child Domestic Servants in Latin America. Population and Development Review, 36(1), 125-149.

Mercado, J. R. (2014). Estado y violencia en el medio rural de México y Brasil. Desacatos. Revista de Ciencias Sociales, 14, 169. https://doi.org/10.29340/14.1092

Minnesota Population Center. (2020). Integrated Public Use Microdata Series, International: Version 7.3 (7.3) [Data set]. Minneapolis, MN: IPUMS. https://doi.org/10.18128/D020.V7.3

Montgomery, M., Stren, R., Cohen, B., \& Reed, H. (2003). Cities Transformed. National Academies Press. https $/ /$ doi.org/10.17226/10693

Moya, J. C. (2007). Domestic service in a global perspective: Gender, migration, and ethnic niches. Journal of Ethnic and Migration Studies, 33(4), 559-579. https://doi.org/10.1080/13691830701265420

Palloni, A. (1990). Fertility and Mortality Decline in Latin America. The Annals of the American Academy of Political and Social Science, 510, 126-144. https://doi.org/10.1177/0002716290510001010

Pinheiro, L., Lira, F., Rezende, M., \& Fontoura, N. (2019). Os Desafios do passado no trabalho doméstico do século XXI: reflexões para o caso brasileiro a partir dos dados da PNAD contínua.

Pinheiro, L. S., Fontoura, N. de O., Querino, A. C., Bonetti, A. de L., \& Rosa, W. (2009). Retrato das desigualdades de gênero e raça.

Portes, A. (1989). Latin American Urbanization during the Years of the Crisis. Latin American Research Review, 24(3), 7-44.

Portes, A. (2006). Institutions and Development: A conceptual Analysis. Population and Development Review, 32(2), 233-262.

Portes, A., \& Hoffman, K. (2003). Latin American Class Structures: Their Composition and Change during the Neoliberal Era. Latin American Research Review, 38(1), 41-82. https://doi.org/10.1353/lar.2003.0011 
Quijano, A. (2000). Coloniality of Power and Eurocentrism in Latin America. International Sociology, 15(2), 215-232. https://doi.org/10.1177/0268580900015002005

Quilodrán, J., \& Juarez, F. (2009). Las pioneras del cambio reproductivo: Un análisis partiendo de sus propios relatos. Notas de Población, 87.

Sánchez-Ancochea, D. (2021). The Costs of Inequality in Latin America: Lessons and Warnings for the Rest of the World. Bloomsbury Publishing Plc. https://doi.org/10.5040/9781838606275

Sassen-Koob, S. (1984). Notes on the Incorporation of Third World Women into Wage-Labor Through Immigration and Off-Shore Production. The International Migration Review, 18(4), 1144-1167.

Schkolnik, S., \& Chackiel, J. (2004). Less advanced sectors in the Latin American fertility transition. Comisión Económica para América Latina y el Caribe.

Shenk, M. K., Towner, M. C., Kress, H. C., \& Alam, N. (2013). A model comparison approach shows stronger support for economic models of fertility decline. Proceedings of the National Academy of Sciences, 110(20), 8045-8050. https://doi.org/10.1073/pnas.1217029110

The World Inequality Lab. (2020). World Inequality Database. https:/wid.world/data/

Tinsman, H. (1992). The Indispensible Services of Sisters: Considering Domestic Service in United States and Latin American Studies. Journal of Women's History, 4(1), 37-59.

Tokman, V. (2010). Domestic Workers in Latin America: Statistics for New Policies (Issue June).

Williams, D. T., \& Baker, R. S. (2021). Family Structure, Risks, and Racial Stratification in Poverty. Social Problems, spab018. https://doi.org/10.1093/socpro/spab018

Williamson, J. G. (2010). Five centuries of Latin American income inequality. Revista de Historia Económica / Journal of Iberian and Latin American Economic History, 28(02), 227-252. https://doi.org/10.1017/S0212610910000078

Woo-Mora, L. G. (2021). Unveiling the Cosmic Race: Racial Inequalities in Latin America. Social Science Research Network, 60.

World Health Organization. (2013). Global and regional estimates of violence against women: Prevalence and health effects of intimate partner violence and non-partner violence (1st ed.). Department of Reproductive Health and Research.

Zuberi, T., \& Bonilla-Silva, E. (2008). White logic, white methods: Racism and methodology. Rowman \& Littlefield Publishers. 